ENVIRONMENTAL RESTORATION PROGRAM

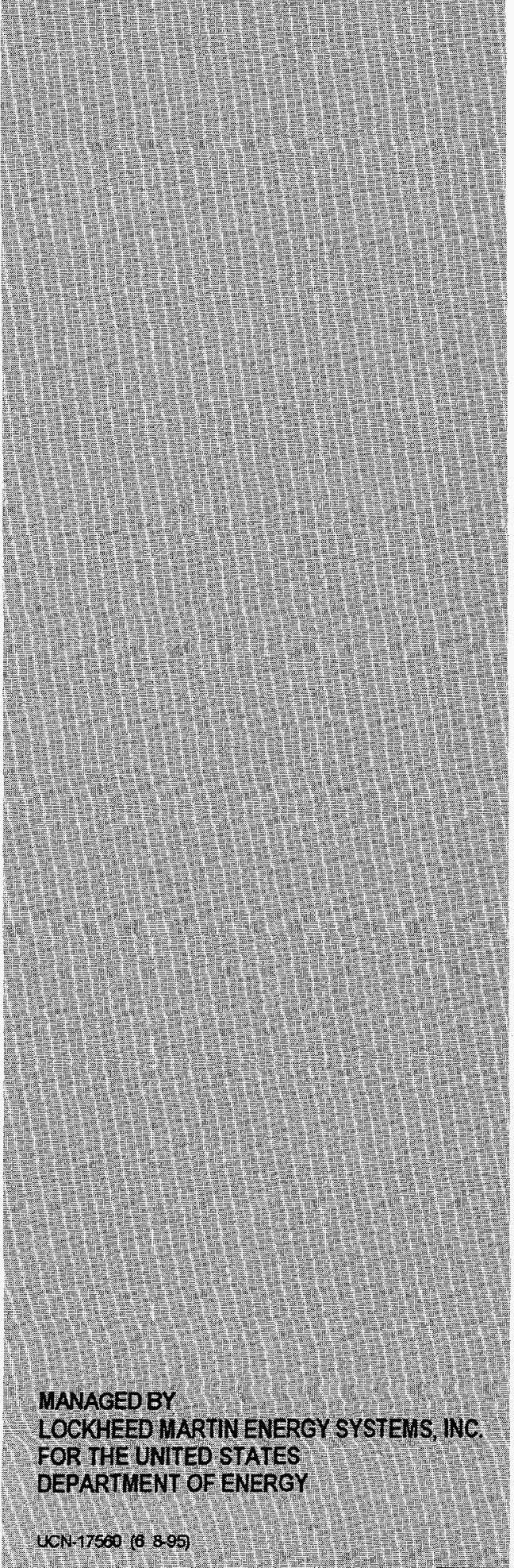

\section{Final Deactivation Report on the Radioisotope Production Lab-C, Building 3030, at Oak Ridge National Laboratory, Oak Ridge, Tennessee}
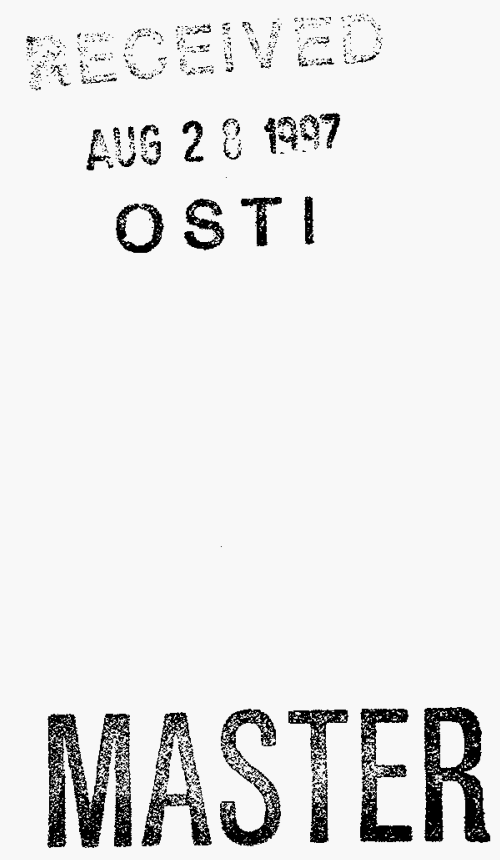

This document has been approved by the ORNL Technical Information Office for release to the public. Date: $8 / 13 / 97$ 

ORNL/ER-408

\title{
Final Deactivation Report on the Radioisotope Production Lab-C, Building 3030, at Oak Ridge National Laboratory, Oak Ridge, Tennessee
}

Date Issued-August 1997

\author{
Prepared for the \\ U.S. Department of Energy \\ Office of Environmental Management \\ under budget and reporting code EW 20 \\ Environmental Management Activities at the \\ OAK RIDGE NATIONAL LABORATORY \\ Oak Ridge, Tennessee 37831 \\ managed by \\ LOCKHEED MARTIN ENERGY SYSTEMS, INC. \\ for the \\ U.S. DEPARTMENT OF ENERGY \\ under contract DE-AC05-84OR21400

\section{DISCLAIMER} \\ This report was prepared as an account of work sponsored by an agency of the United States \\ Government. Neither the United States Government nor any agency thereof, nor any of their \\ empleyees, makes any warranty, express or implied, or assumes any legal liability or responsi- \\ bility for the accuracy, completeness, or usefulness of any information, apparatus, product, or \\ process disclosed, or represents that its use would not infringe privately owned rights. Refer- \\ ence herein to any specific commercial product, process, or service by trade name, trademark, \\ manufacturer, or otherwise does not necessarily constitute or imply its endorsement, recom- \\ mendation, or favoring by the United States Government or any agency thereof. The views \\ and opinions of authors expressed herein do not necessarily state or reflect those of the \\ United States Government or any agency thereof.
}

DISTRIBUTION OF THIS DOCUMENT IS UNLMITED 



\section{DISCLAMMER}

Portions of this document may be illegible in electronic image products. Images are produced from the best available original document. 



\section{PREFACE}

This is the Final Deactivation Project Report on the Radioisotope Production Lab-C, Building 3030, at Oak Ridge National Laboratory, Oak Ridge, Tennessee (ORNL/ER-408). Although this element of work is not part of the Comprehensive Environmental Response, Compensation, and Liability Act of 1980, it was accomplished in accordance with the substantive requirements of the Act. This work was performed under Work Breakdown Structure 1.6.6.2.10.02, Activity Data Sheet 6504IS, "Isotopes Facilities Deactivation Project." This document provides the Environmental Management and Enrichment Facilities Program with the final report on the deactivation of Bldg. 3030 . 



\section{CONTENTS}

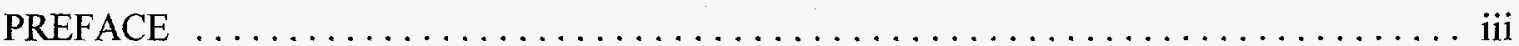

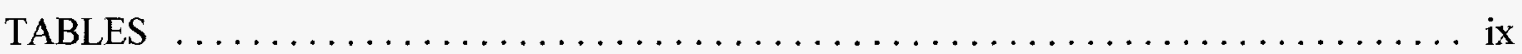

ABBREVIATIONS $\ldots \ldots \ldots \ldots \ldots \ldots \ldots \ldots \ldots \ldots \ldots \ldots \ldots \ldots \ldots \ldots \ldots \ldots \ldots \ldots$

DEFINITIONS $\ldots \ldots \ldots \ldots \ldots \ldots \ldots \ldots \ldots \ldots \ldots \ldots \ldots \ldots \ldots \ldots \ldots \ldots \ldots \ldots \ldots \ldots \ldots \ldots$

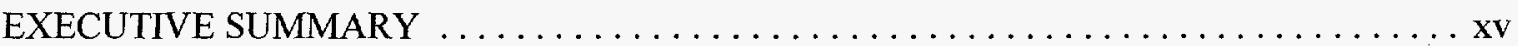

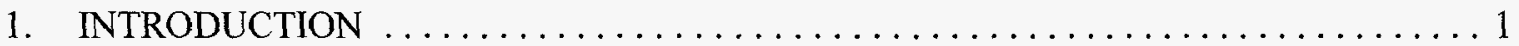

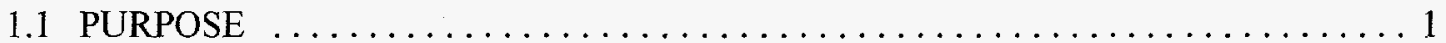

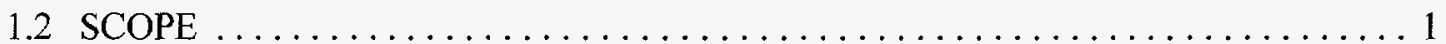

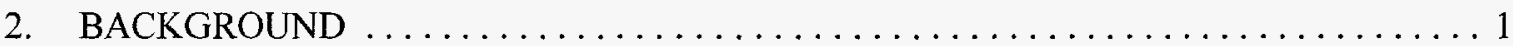

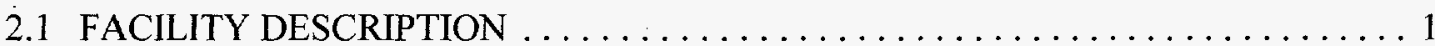

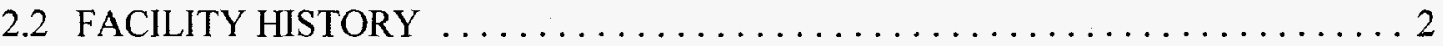

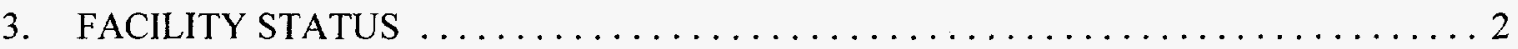

3.1 PREDEACTIVATION FACILITY STATUS $\ldots \ldots \ldots \ldots \ldots \ldots \ldots \ldots \ldots \ldots \ldots \ldots \ldots \ldots \ldots$

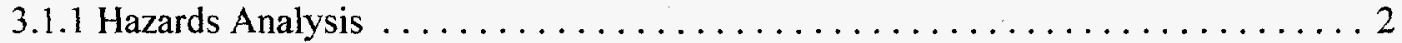

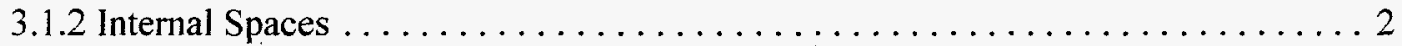

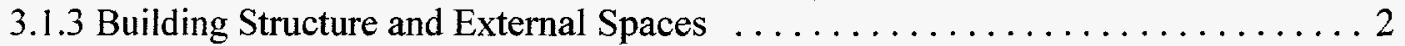

3.1.4 Process, Utility, and Support Systems . . . . . . . . . . . . . . 3

3.1.5 Radioactive Material, Contamination, and Waste . . . . . . . . . . . . . 4

3.1.6 Hazardous Materials and Waste ......................... 5

3.2 POST DEACTIVATION FACILITY STATUS $\ldots \ldots \ldots \ldots \ldots \ldots \ldots \ldots \ldots \ldots \ldots \ldots$

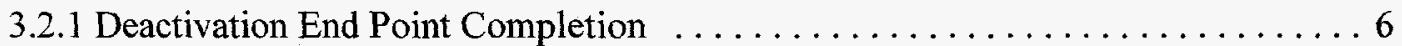

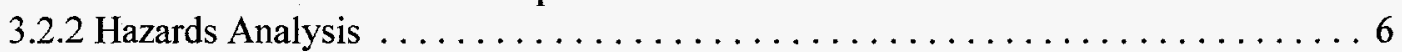

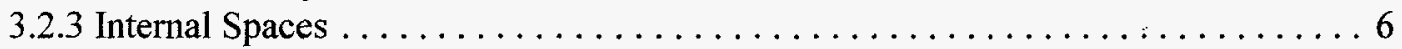

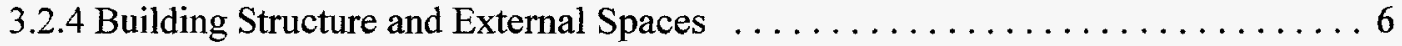

3.2 .5 Process, Utility, and Support Systems . . . . . . . . . . . . . . . 6

3.2.6 Radioactive Material, Contamination, and Waste $\ldots \ldots \ldots \ldots \ldots \ldots \ldots$

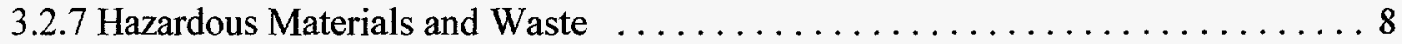

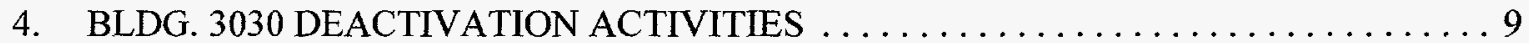

4.1 INTERNAL SPACES; ACCESS REQUIRED $\ldots \ldots \ldots \ldots \ldots \ldots \ldots \ldots \ldots$

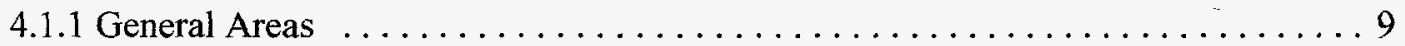

4.2 INTERNAL SPACES; NO ACCESS REQUIRED $\ldots \ldots \ldots \ldots \ldots \ldots \ldots \ldots$

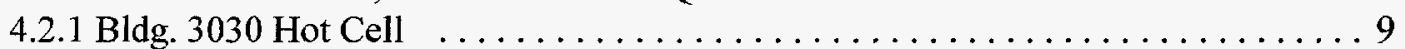

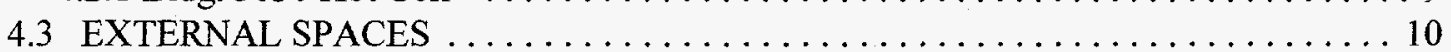

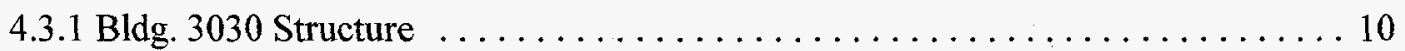

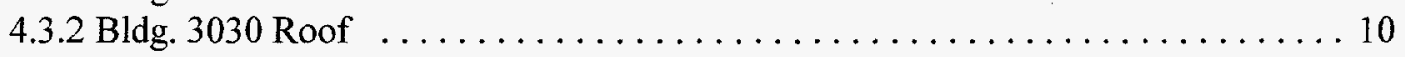




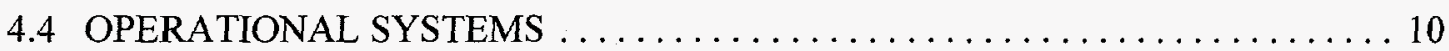

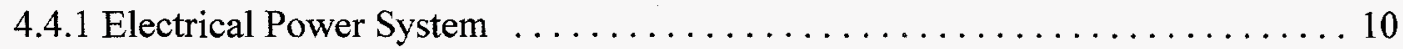

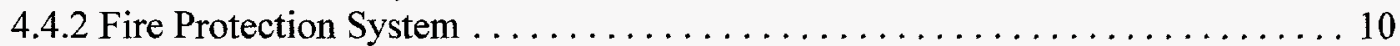

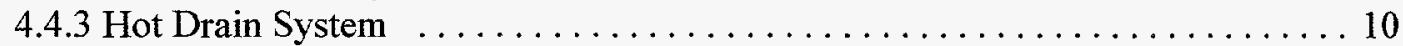

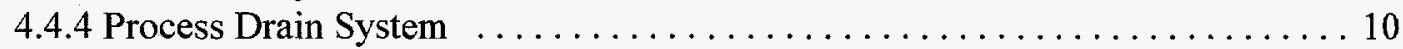

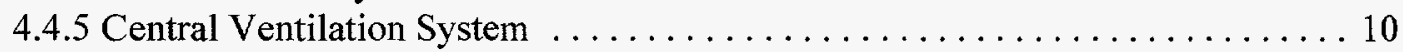

4.4.6 Local Ventilation System ............................ 10

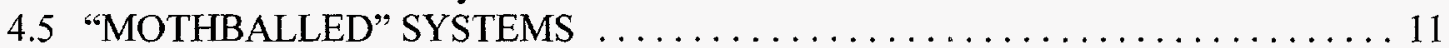

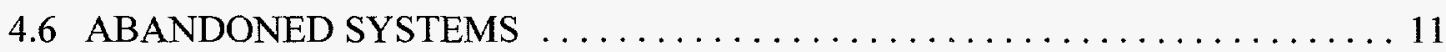

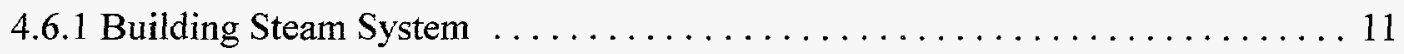

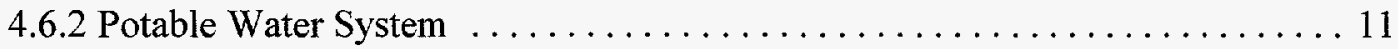

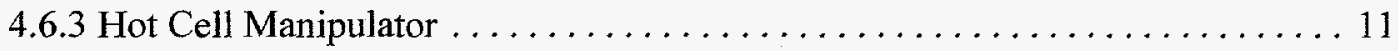

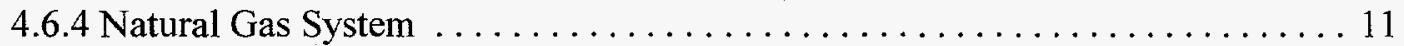

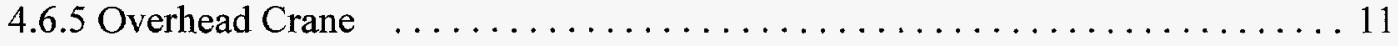

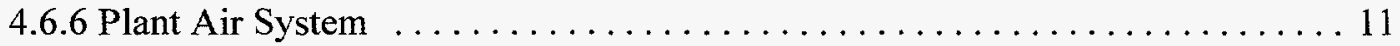

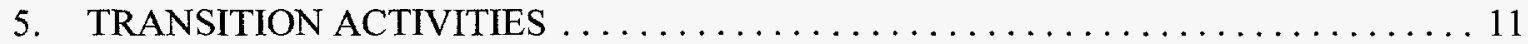

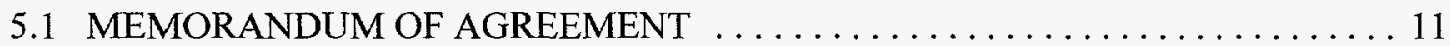

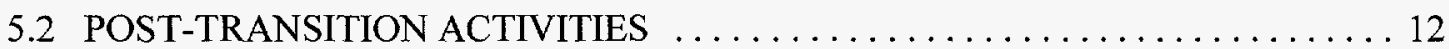

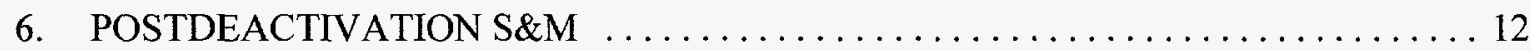

7. ABNORMAL ACTIVITIES/CONDITIONS $\ldots \ldots \ldots \ldots \ldots \ldots \ldots \ldots \ldots \ldots \ldots \ldots \ldots \ldots$

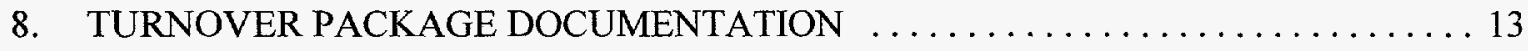

8.1 ADMINISTRATIVE TURNOVER PACKAGE $\ldots \ldots \ldots \ldots \ldots \ldots \ldots \ldots \ldots \ldots \ldots$

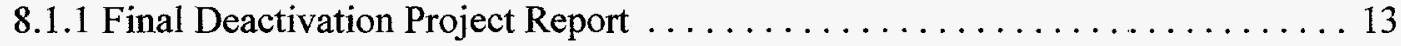

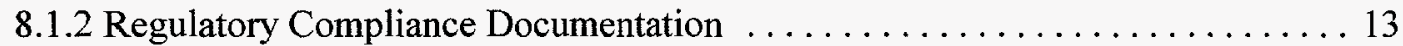

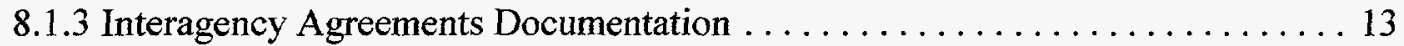

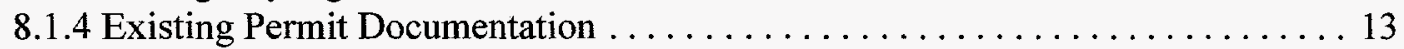

8.1.5 Corrective Action Documentation . . . . . . . . . . . . . . . . . . 13

8.1.6 Deactivation Locks and Keys . . . . . . . . . . . . . . . . . . 14

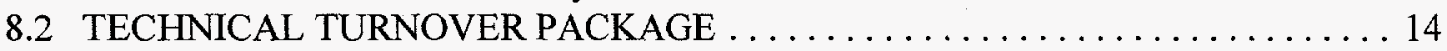

8.2.1 Updated Facility Drawings (Arrangements, PID, Loop, Etc.) . . . . . . . . . 14

8.2.2 "As Left" Photos of Spaces and Major Equipment . . . . . . . . . . 14

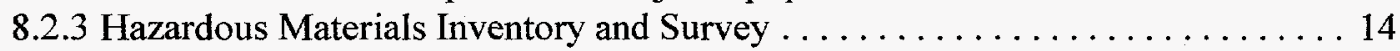

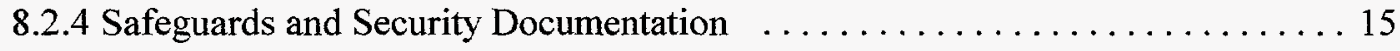

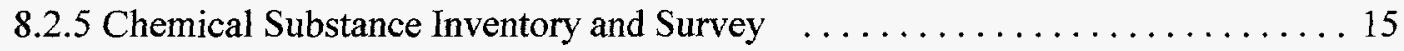

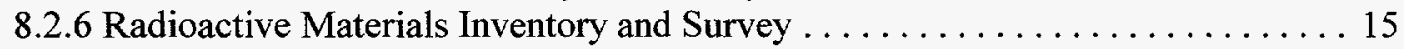

8.2.7 Facility Soil, Surface Water, and Groundwater Condition Report ......... 15

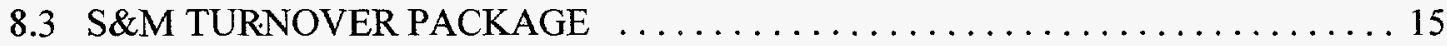

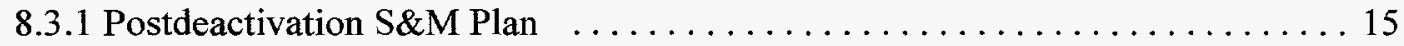

8.3.2 Postdeactivation S\&M Updated Safety Equipment List $\ldots \ldots \ldots \ldots \ldots \ldots \ldots$

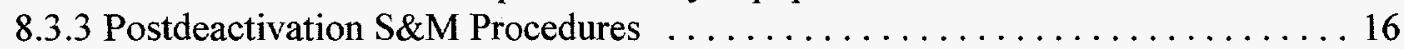

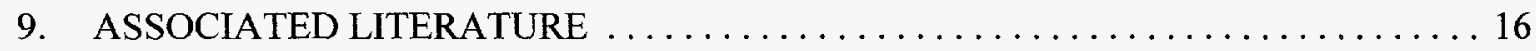

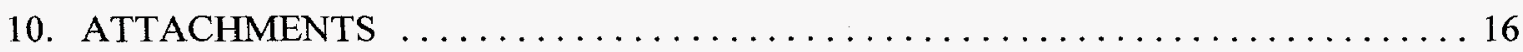


ATTACHMENT1 BLDG. 3030 FLOOR PLAN $\ldots \ldots \ldots \ldots \ldots \ldots \ldots \ldots \ldots \ldots \ldots \ldots$

ATTACHMENT 2 BLDG. 3030 PREDEACTIVATION FACILITY PHOTOGRAPHS $\ldots$. 2-1

ATTACHMENT 3 BLDG. 3030 POSTDEACTIVATION FACILITY PHOTOGRAPHS . . . 3-1

ATTACHMENT 4 ADMINISTRATIVE TURNOVER PACKAGE CHECKLIST $\ldots \ldots$ 4-1

ATTACHMENT 5 TECHNICAL TURNOVER PACKAGE CHECKLIST $\ldots \ldots \ldots \ldots$ 5-1

ATTACHMENT 6 BLDG. 3030 DRAWING LIST $\ldots \ldots \ldots \ldots \ldots \ldots \ldots \ldots \ldots \ldots \ldots$

ATTACHMENT 7 BLDG. 3030 RADIOLOGICAL SURVEY DATA . . . . . . . 7-1

ATTACHMENT 8 S\&M TURNOVER PACKAGE CHECKLIST $\ldots \ldots \ldots \ldots \ldots \ldots$. 


\section{TABLES}

1. Predeactivation Radioactive Contamination Levels . . . . . . . . . . . . . . . . 5

2. Predeactivation Radiation Levels . . . . . . . . . . . . . . . . . . . . . . . . . . 5

3. Bldg. 3030 Predeactivation Hazardous Materials and Waste $\ldots \ldots \ldots \ldots \ldots \ldots \ldots \ldots \ldots$

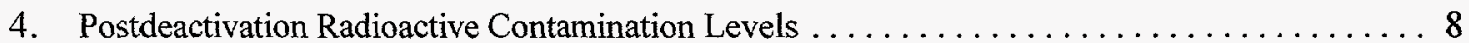

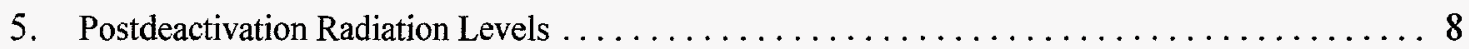

6. Bldg. 3030 Postdeactivation Hazardous Materials and Waste $\ldots \ldots \ldots \ldots \ldots \ldots \ldots . \ldots$

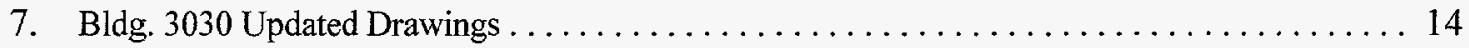

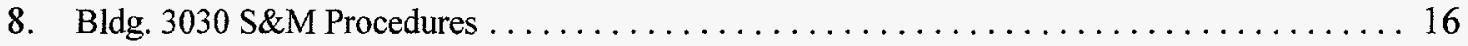





\section{ABBREVIATIONS}

$D \& D$

DOE

EM-40

EM-60

FDPR

MOA

ORNL

$S \& M$
Decontamination and Decommissioning

U.S. Department of Energy

Department of Energy Office of Environmental Restoration

Department of Energy Office of Facility Transition and Management

Final Deactivation Project Report

Memorandum of Agreement

Oak Ridge National Laboratory

Surveillance and Maintenance 



\section{DEFINITIONS}

Commitments

Deactivation

Decommissioning

Decontamination

Defense-in-Depth

End Point

End Point

Technical Information

Stakeholder

Turnover Package
Tasks required to be accomplished to meet non-regulatory requirements. (site, stakeholders, etc.)

The process of placing a facility in a safe and stable condition to minimize the long-term cost of a surveillance and maintenance program that is protective of workers, the public, and the environment until decommissioning is completed.

Refers to the ultimate disposition of a facility. Also substitutes for previously used "D\&D."

The removal or reduction of radioactive or hazardous contamination from facilities, equipment, or soils by washing, heating, chemical or electro-chemical action, mechanical cleaning or other techniques to achieve a stated objective or end condition.

Achieving required levels of safety and protection there is more than one layer of protection between the hazard and that which is being protected.

A detailed specification for the final deactivation condition of areas and hardware within a facility and related documentation. An individual milestone towards the deactivation and/or the decommissioning of a facility.

A compilation of documents to support end point conclusions. Individuals and organizations (i.e. regulators, local municipalities, the public, etc.) who may be directly or indirectly impacted by activities associated with the IFDP.

A compilation of project related documents to be given to a postdeactivation organization. 



\section{EXECUTIVE SUMMARY}

The purpose of this report is to document the condition of Bldg. 3030 after completion of deactivation activities as outlined by the Department of Energy (DOE) Office of Nuclear Materials and Facility Stabilization Program (EM-60) guidance documentation. This report outlines the activities conducted to place the facility in a safe and environmentally sound condition for transfer to DOE's Office of Environmental Restoration Program (EM-40).

This report provides profile of Bldg. 3030 before and after deactivation activities. Turnover items, such as the Postdeactivation Surveillance \& Maintenance Plan, remaining hazardous materials, radiological controls, Safeguards and Security, QA, facility operations, and supporting documentation provided in the Office of Nuclear Materials and Facility Stabilization Program (EM-60) Turnover package are discussed.

Building 3030 will require access to facilitate required S\&M activities to maintain the building safety envelope. Building 3030 was stabilized during deactivation so that when transferred to the EM-40 program, only a minimal S\&M effort would be required to maintain the building's safety envelope. Other than the minimal S\&M activities, the building will be unoccupied and the exterior doors locked to prevent unauthorized access. The building will be entered only for required S\&M.

All materials have been removed from the building and the hot cell, and all utility systems, piping, and alarms have been deactivated. 



\section{INTRODUCTION}

\subsection{PURPOSE}

This report documents the condition of Bldg. 3030 after completion of deactivation activities as outlined by the Department of Energy (DOE) Office of Nuclear Materials and Facility Stabilization (EM-60) Program guidance documentation. This report outlines the activities conducted to place the facility in a safe and environmentally sound condition for transfer to the DOE Office of Environmental Restoration (EM-40) Program.

This report provides a profile of the facility before and after deactivation activities. Turnover items, such as the Postdeactivation Surveillance \& Maintenance Plan, remaining hazardous materials, radiological controls, Safeguards and Security, QA, facility operations, and supporting documentation provided in the EM-60 Turnover package are discussed.

\subsection{SCOPE}

This report addresses the activities performed during deactivation associated with Bldg. 3030 , to place the facility in a safe and environmentally sound condition to await decommissioning, the status of the facility, and the activities required to maintain the facility following deactivation. Attachment 1, "Building 3030 Floor Plan," provides a floor plan of Bldg. 3030 that illustrates the physical boundaries and scope of this Final Deactivation Project Report (FDPR). The scope of this FDPR is limited to Bldg. 3030.

\section{BACKGROUND}

\subsection{FACILITY DESCRIPTION}

Building 3030 is a steel-frame structure covered by corrugated aluminum siding. The singlestory facility has a floor area of $825 \mathrm{ft}^{2}$. A manipulator-type hot cell is located on the middle of the east wall. Two laboratory-type hoods occupy the northeast corner of the building with one laboratory-type hood occupying the center of the north wall of the building. A laboratory-type workbench occupies the center of the facility and is equipped with a sink. The manipulator cell and laboratory hoods constitute the primary means of containment. All high-level work was conducted in the hot cell. The building operates at a slightly negative pressure relative to the outside atmosphere.

The hot cell has 2-ft barytes concrete walls with 4 in. of lead brick shielding on the operating face of the cell wall and an unshielded top cover. The cell has a mineral-oil-filled, lead glass window. A stainless steel operating pan covers the floor and interior walls up to the level of the viewing window. A small steel door on the north side of the cell is used for the insertion and removal of small equipment and containers. A thick steel double door at the back of the cell provides access for larger items if needed. 
Extended reach Model-8 manipulators are inserted through holes in the top of the cell. The slave sections of the manipulators are covered with urethane manipulator boots sealed to the inside top surfaces of the cells. An additional plastic boot and wiper seals in the manipulator barrels provide secondary containment for manipulator penetration.

\subsection{FACILITY HISTORY}

Building 3030 was constructed in 1950 as part of the Isotopes Program. The building contains facilities that were used for storage purification and processing and dispensing of a wide variety of radioisotopes. These isotopes were processed primarily from irradiated targets from the High Flux Isotope Reactor, the Oak Ridge Research Reactor, and the 86-in. Cyclotron.

\section{FACILITY STATUS}

\subsection{PREDEACTIVATION FACILITY STATUS}

Following approximately 40 years of operations and processing, Bldg. 3030 was surplused, and many of the process systems were abandoned in place. General housekeeping was not maintained, and the building structural integrity was allowed to lapse.

Attachment 2, "Predeactivation Facility Photographs," contains photographs of the building conditions prior to deactivation activities.

\subsubsection{Hazards Analysis}

No predeactivation hazards analysis was performed. Since only process activities involving less than 100 ci were performed in Bldg. 3030, it was determined that the facility did not warrant a hazard analysis or safety analysis.

\subsubsection{Internal Spaces}

The general area contained furniture, cabinets, hazardous waste, radioactive waste, and miscellaneous items used when the facility was in operation. The lead-based paint is chipping and peeling, providing a means of transferring lead and endangering personnel and the environment.

Predeactivation radioactive contamination levels and radiation levels for the general area are listed in Tables 1 and 2, respectively. Table 3 lists predeactivation hazardous materials and waste located in the general area.

\subsubsection{Building Structure and External Spaces}

The structure and roof of Bldg. 3030 were inspected and found to be in generally good condition, with the exception of water inleakage through various paths. 


\subsubsection{Process, Utility, and Support Systems}

\subsubsection{Electrical power system}

Prior to deactivation, the electrical power system provided power distribution for the electrical service to Bldg. 3030. Typical electrical loads were the lighting, heaters, and exhaust fans. A 480VAC outlet also existed for use with welders and other equipment requiring this service.

\subsubsection{Fire protection system}

The fire protection system is a dry pipe fire suppression system for Bldg. 3030 and is available for use. The general area was equipped with sprinkler heads and alarms as required by the local fire code. In addition, fire extinguishers were placed strategically in and around Bldg. 3030.

The fire protection system is not believed to be contaminated.

\subsubsection{Building steam system}

The building steam system provided steam for use in heating the general area of Bldg. 3030 . Two heat exchangers located in Bldg. 3030 provided space heating for personnel.

The building steam system is not believed to be contaminated. However, most of the steam piping within Bldg. 3030 is lagged with asbestos insulation materials.

\subsubsection{Potable water system}

Prior to deactivation, the potable water system provided water to the Bldg. 3030 safety shower, water heater, and sink. The potable water system is not believed to be contaminated.

\subsubsection{Hot drain system}

Prior to deactivation, the hot drain system provided a means of discharging liquid process wastes from the hot cells to the LLLW system. The hot drain system is a gravity drain system to the WC-10 tank in the low-level liquid waste (LLLW) system.

The hot drain system was determined to be highly contaminated from the process and cleaning activities performed prior to deactivation.

\subsubsection{Process drain system}

Prior to deactivation, the process drain system provided a means of removing liquids from the area floor to the ORNL process waste system and treatment facility. The process drain system is a gravity drain system.

The process drain system was determined to be contaminated from the process and cleaning activities performed prior to deactivation. 


\subsubsection{Natural gas system}

The natural gas system to Bldg. 3030 was never used. The system has remained isolated from the building since the time of its installation and is not believed to be contaminated.

\subsubsection{Overhead crane}

Prior to deactivation, an overhead crane was used in Bldg. 3030 to provide a means of moving heavy equipment in and around the hot cell. The overhead crane was determined to be contaminated from the process activities performed prior to deactivation.

\subsubsection{Plant air system}

Prior to deactivation, the plant air system provided 110 psig air to Bldg. 3030 . The plant air system was regulated and used for process activities and instrumentation throughout the facility. The plant air system is not believed to be contaminated.

\subsubsection{Hot cell manipulators}

Prior to deactivation, the hot cell manipulators provided a means of remote process operation within the hot cell. The hot cell is equipped with Model 8 manipulators.

Prior to deactivation, the hot cell manipulator boots and seals were determined to be in poor condition and a potential for the spread of contamination from the hot cells.

\subsubsection{Central ventilation system}

Prior to deactivation, the central ventilation system provided exhaust ventilation services to the hot cell in Bldg. 3030. The central ventilation system for Bldg. 3030 was filtered through HEPA filters prior to discharge to the 3039 stack.

The central ventilation system was determined to be contaminated from the process activities performed prior to deactivation.

\subsubsection{Local ventilation system}

Prior to deactivation, the local ventilation system provided exhaust ventilation services to the hoods in Bldg. 3030. The local ventilation system for Bldg. 3030 was filtered through HEPA filters prior to discharging to the atmosphere.

The local ventilation system was determined to be very slightly contaminated from the process activities performed prior to deactivation.

\subsubsection{Radioactive Material, Contamination, and Waste}

Table 1 lists the radioactive contamination levels identified on radiation surveys conducted prior to deactivation. 
Table 1. Predeactivation Radioactive Contamination Levels

\begin{tabular}{lll}
\hline \multicolumn{1}{c}{ Identification } & \multicolumn{1}{c}{ Description } & \multicolumn{1}{c}{ Quantity } \\
\hline Hot cell & alpha smear - transferable contamination & less than $500 \mathrm{dpm} / 100 \mathrm{~cm}^{2}$ \\
Hot cell & beta/gamma smear - transferable contamination & up to $21 \mathrm{mRad} / \mathrm{h} / 100 \mathrm{~cm}^{2}$ \\
Hood $\# 1, \# 2, \# 3$ & alpha smear - transferable contamination & less than $500 \mathrm{dpm} / 100 \mathrm{~cm}^{2}$ \\
Hood $\# 1$ & beta/gamma smear - transferable contamination & $1799 \mathrm{dpm} / 100 \mathrm{~cm}^{2}$ \\
Hood $\# 2$ & beta/gamma smear - transferable contamination & $5943 \mathrm{dpm} / 100 \mathrm{~cm}^{2}$ \\
Hood \#3 & beta/gamma smear - transferable contamination & $1134 \mathrm{dpm} / 100 \mathrm{~cm}^{2}$ \\
General area & alpha smear - transferable contamination & less than $500 \mathrm{dpm} / 100 \mathrm{~cm}^{2}$ \\
General area & beta/gamma smear - transferable contamination & up to $350,000 \mathrm{P} \mathrm{dpm} / 100 \mathrm{~cm}^{2}$ \\
\hline
\end{tabular}

Table 2 lists radiation levels identified on radiation surveys conducted prior to deactivation:

Table 2. Predeactivation Radiation Levels

\begin{tabular}{lll}
\hline Identification & \multicolumn{1}{c}{ Description } & \multicolumn{1}{c}{ Quantity } \\
\hline Hot cell & fixed and transferable radiation levels & $1 \mathrm{Rem} / \mathrm{hr}$ \\
Hood $\# 1$ & fixed and transferable radiation levels & $1.5 \mathrm{mRem} / \mathrm{hr}$ \\
Hood $\# 2$ & fixed and transferable radiation levels & $6 \mathrm{mRem} / \mathrm{hr}$ \\
Hood $\# 3$ & fixed and transferable radiation levels & $20 \mathrm{mRem} / \mathrm{hr}$ \\
General area & fixed and transferable radiation levels & up to $1.2 \mathrm{mRem} / \mathrm{hr}$ \\
\hline
\end{tabular}

\subsubsection{Hazardous Materials and Waste}

Table 3 lists the hazardous materials and waste identified during facility walkdowns prior to deactivation.

Table 3. Bldg. 3030 Predeactivation Hazardous Materials and Waste

\begin{tabular}{lll}
\hline \multicolumn{1}{c}{ Identification } & \multicolumn{1}{c}{ Description } & \multicolumn{1}{c}{ Quantity } \\
\hline Lead-based paint & Used as wall covering throughout building. & indeterminate \\
Asbestos floor tiles & Used as floor covering throughout the building. & approx. \\
& & $825 \mathrm{ft}^{2}$ \\
Asbestos lagging & Used as pipe lagging throughout the building & indeterminate \\
PCBs & Electrical devices and transformers & indeterminate \\
Lead shielding & Used in hot cell walls and window & indeterminate \\
Mineral oil & Used in hot cell window & indeterminate \\
\hline
\end{tabular}

\subsection{POST DEACTIVATION FACILITY STATUS}

Attachment 3, "Postdeactivation Facility Photographs," contains photographs of the building conditions following deactivation activities. 


\subsubsection{Deactivation End Point Completion}

End point criteria for deactivation activities and end point completion documentation are not applicable for Bldg. 3030. The requirement and guidance for these program elements were not developed prior to Bldg. 3030 deactivation.

\subsubsection{Hazards Analysis}

A postdeactivation hazards screening was performed. This hazards screening placed the facility in the "other industrial" category.

\subsubsection{Internal Spaces}

The miscellaneous items abandoned when the facility was no longer in use have been removed from the general area. No significant combustibles remain in the general area and the general area of Bldg. 3030 has been decontaminated to remove transferable contamination from access-required spaces. The lead-based paint is chipping and peeling, providing a means of transferring the lead and endangering personnel and the environment.

Postdeactivation radioactive contamination levels and radiation levels for this area are listed in Tables 4 and 5 respectively. Postdeactivation hazardous materials and waste located in this area are listed in Table 6.

\subsubsection{Building Structure and External Spaces}

The structure and roof of Bldg. 3030 were inspected and found to be in generally good condition, with the exception of some water inleakage through various paths.

\subsubsection{Process, Utility, and Support Systems}

\subsubsection{Electrical power system}

All electrical services, with the exception of lighting, have been disconnected or de-energized at the main breaker box.

\subsubsection{Fire protection system} building.

The fire protection system is a dry system and remains available for use if there is a fire in the

\subsubsection{Building steam system}

The building steam system has been isolated, drained, and abandoned in place.

\subsubsection{Potable water system}

The potable water system has been isolated, drained, and abandoned in place. 


\subsubsection{Hot Drain System}

The hot drain system has been abandoned in place. All hot cell drains have been plugged to isolate the hot cells and to prevent the potential spread of contamination.

The hot drain system remains highly contaminated from the process and cleaning activities performed prior to deactivation.

\subsubsection{Process Drain System}

The process drain system has been abandoned in place. However, the process drain system remains connected to the ORNL process waste system.

The process drain system remains contaminated from the process and cleaning activities performed prior to deactivation.

\subsubsection{Natural Gas System}

The natural gas system has been isolated, vented, and abandoned in place.

\subsubsection{Overhead Crane}

The overhead crane has been de-energized and abandoned in place. It remains contaminated from the process activities performed prior to deactivation.

\subsubsection{Plant Air System}

The plant air system has been isolated, vented, and abandoned in place.

\subsubsection{Hot cell manipulators}

The hot cell manipulator boots and isolation bags were removed and replaced. New boots were placed on the in-cell portion of the manipulators. The plastic boot and wiper seals around the manipulator were removed. The manipulator control arms are bagged as an added precaution.

\subsubsection{Central ventilation system}

The central ventilation system remains in operation to provide negative pressure for contamination control for the hot cell. All controls associated with the central ventilation system remain in operation as well.

The central ventilation system remains highly contaminated from the process activities performed prior to deactivation.

\subsubsection{Local ventilation system}

The local ventilation system has been removed from service and shutdown. It is slightly contaminated from the process activities performed prior to deactivation. 


\subsubsection{Radioactive Material, Contamination, and Waste}

Table 4 lists the radioactive contamination levels identified on radiation surveys conducted following deactivation.

Table 4. Postdeactivation Radioactive Contamination Levels

\begin{tabular}{|c|c|c|}
\hline Identification & Description & Quantity \\
\hline Hot cell & alpha smear - transferable contamination & less than $500 \mathrm{dpm} / 100 \mathrm{~cm}^{2}$ \\
\hline Hot cell & $\begin{array}{l}\text { beta/gamma smear - transferable } \\
\text { contamination }\end{array}$ & 1.0 to $100000 \mathrm{dpm} / 100 \mathrm{~cm}^{2}$ \\
\hline Hood \#1 & alpha smear - transferable contamination & less than $500 \mathrm{dpm} / 100 \mathrm{~cm}^{2}$ \\
\hline Hood \#1 & $\begin{array}{l}\text { beta/gamma smear - transferable } \\
\text { contamination }\end{array}$ & No detectable contamination \\
\hline Hood $\# 2$ & alpha smear - transferable contamination & less than $500 \mathrm{dpm} / 100 \mathrm{~cm}^{2}$ \\
\hline Hood \#2 & $\begin{array}{l}\text { beta/gamma smear - transferable } \\
\text { contamination }\end{array}$ & No detectable contamination \\
\hline Hood \#3 & alpha smear - transferable contamination & less than $500 \mathrm{dpm} / 100 \mathrm{~cm}^{2}$ \\
\hline Hood \#3 & $\begin{array}{l}\text { beta/gamma smear - transferable } \\
\text { contamination }\end{array}$ & No detectable contamination \\
\hline General area & alpha smear - transferable contamination & less than $500 \mathrm{dpm} / 100 \mathrm{~cm}^{2}$ \\
\hline General area & $\begin{array}{l}\text { beta/gamma smear - transferable } \\
\text { contamination }\end{array}$ & No detectable contamination \\
\hline
\end{tabular}

Table 5 lists radiation levels identified on radiation surveys conducted prior to deactivation.

Table 5. Postdeactivation Radiation Levels

\begin{tabular}{lll}
\hline \multicolumn{1}{c}{ Identification } & \multicolumn{1}{c}{ Description } & \multicolumn{1}{c}{ Quantity } \\
\hline Hot cell & fixed and transferable radiation levels & $22 \mathrm{mRem} / \mathrm{hr}$ \\
Hood $\# 1$ & fixed and transferable radiation levels & $0.2 \mathrm{mRem} / \mathrm{hr}$ \\
Hood $\# 2$ & fixed and transferable radiation levels & $0.3 \mathrm{mRem} / \mathrm{hr}$ \\
Hood \#3 & fixed and transferable radiation levels & $5.0 \mathrm{mRem} / \mathrm{hr}$ \\
General area & fixed and transferable radiation levels & $0.1 \mathrm{mRem} / \mathrm{hr}$ \\
\hline
\end{tabular}

\subsubsection{Hazardous Materials and Waste}

Table 6 lists the hazardous materials and waste identified during facility walkdowns following deactivation

Table 6. Bldg. 3030 Postdeactivation Hazardous Materials and Waste

\begin{tabular}{lll}
\hline Identification & \multicolumn{1}{c}{ Description } & Quantity \\
\hline $\begin{array}{l}\text { Lead-based } \\
\text { paint }\end{array}$ & Used as wall covering throughout building & indeterminate \\
$\begin{array}{l}\text { Asbestos floor } \\
\text { tiles }\end{array}$ & Used as floor covering throughout the building & approx. 825 $\mathrm{ft}^{2}$
\end{tabular}


Table 6. (continued)

\begin{tabular}{lll}
\hline Identification & \multicolumn{1}{c}{ Description } & \multicolumn{1}{c}{ Quantity } \\
\hline Asbestos & Used as pipe lagging throughout the building & indeterminate \\
Lagging & & \\
PCBs & Electrical devices and transformers & indeterminate \\
Lead shielding & Used in hot cell walls and window & indeterminate \\
Mineral oil & Used in hot cell window & indeterminate \\
\hline
\end{tabular}

\section{BLDG. 3030 DEACTIVATION ACTIVITIES}

The following section addresses the major activities performed during the deactivation of Bldg. 3030. The objectives of the deactivation process were to place the facility in a passively safe and environmentally stable configuration that can be efficiently and cost-effectively maintained indefinitely. The major deactivation issues, with regard to Bldg. 3030, are listed below:

\subsection{INTERNAL SPACES; ACCESS REQUIRED}

\subsubsection{General Areas}

All storage cabinets, desks, file cabinets, and miscellaneous office materials were removed from the building. Some were green-tagged for reuse. The remaining items were disposed of.

The asbestos floor tiles were not removed and are not intended to be removed until facility decontamination and decommissioning.

The walls in the building are covered with lead-based paint. Peeling and flaking areas have been repaired, but the remainder of the paint will remain as is. Paint condition is an inspection item in the S\&M plan for Bldg. 3030.

\subsection{INTERNAL SPACES; NO ACCESS REQUIRED}

\subsubsection{Hot Cell}

The following deactivation activities were performed in the hot cell:

- The hot cell manipulator boots and isolation bags were removed and replaced. New boots were placed on the in-cell portion of the manipulators. The plastic boot and wiper seals around the manipulator were removed.

- The hot cell was wiped down to reduce airborne contamination.

- All hot cell service lines were identified, labeled, and plugged.

- All in-cell filters were removed.

- All hot cell drains were plugged.

- Access to the hot cell was secured. 


\subsection{EXTERNAL SPACES}

\subsubsection{Bldg. 3030 Structure}

The exterior of Bldg. 3030 was inspected and found to be in generally good structural condition. The building exterior has been cocooned to eliminate air and water inleakage and to provide effective containment for the building.

\subsubsection{Bldg. 3030 Roof}

The roof of Bldg. 3030 was repaired/inspected and found to be in generally good structural condition.

\subsection{OPERATIONAL SYSTEMS}

\subsubsection{Electrical Power System}

All electrical services that were not essential to the basic surveillance and maintenance operations were disconnected at the main breaker box.

\subsubsection{Fire Protection System}

The fire protection system is a dry pipe delivery system available in case of a building fire.

\subsubsection{Hot Drain System}

The hot cell drains were plugged with Plexiglas plugs to isolate the hot cells and prevent the spread of contamination. No decontamination of the hot drain system has been performed.

\subsubsection{Process Drain System}

The process floor drains remain in operation to direct any roof inleakage to the ORNL process waste system and prevent any uncontrolled contamination from leaving the building. No decontamination of the process drain system has been performed.

\subsubsection{Central Ventilation System}

The central ventilation system remains in operation to provide negative pressure for contamination control for the hot cell. All controls associated with this system remain in operation as well. No decontamination of the central ventilation system has been performed.

\subsubsection{Local Ventilation System}

The local ventilation system has been removed from service and shut down in place. No decontamination of the local ventilation system has been performed. 


\section{5 "MOTHBALLED" SYSTEMS}

There are no "mothballed" systems associated with Bldg. 3030.

\subsection{ABANDONED SYSTEMS}

\subsubsection{Building Steam System}

The building steam system supply was drained and valved off.

\subsubsection{Potable Water System}

The incoming line of the potable water system has been capped, isolating the system from Bldg. 3030 .

\subsubsection{Hot Cell Manipulators}

The hot cell manipulator boots and isolation bags were removed and replaced. New boots were placed on the in-cell portion of the manipulators. The plastic boot and wiper seals around the manipulator were removed. Decontamination was performed, as required, during manipulator boot replacement.

\subsubsection{Natural Gas System}

The natural gas system was vented and valved off.

\subsubsection{Overhead Crane}

The overhead crane was de-energized and abandoned in place. Minor decontamination was performed on the overhead crane to minimize the potential spread of contamination.

\subsubsection{Plant Air System}

The plant air system has been depressurized and valved off.

\section{TRANSITION ACTIVITIES}

Building 3030 will be officially transferred from DOE's EM-60 program to the EM-40 program by a Memorandum of Agreement (MOA). The building will be accepted "as is" by EM-40 at the time of transfer.

\subsection{MEMORANDUM OF AGREEMENT}

The MOA documents the requirements agreed upon between EM-40 and EM- 60 . The signed MOA indicates acceptance by EM-40 that the criteria outlined in the MOA have been completed 
satisfactorily, with the exception of post-transition punchlist items, and that the level of deactivation of the facility is acceptable for transition to the EM-40 program.

Post-transition punchlist items will be finished after deactivation is complete. The details of how the punchlist items will be completed and documented will be addressed in the MOA.

\subsection{POST-TRANSITION ACTIVITIES}

No Post-Transition punchlist items have been identified for Bldg. 3030. All deactivation activities have been completed prior to transfer to EM-40.

\section{POSTDEACTIVATION S\&M}

The "Postdeactivation S\&M Plan for Building.3030" covers S\&M activities associated with the interior spaces, operational and mothballed systems, and external areas related to Bldg. 3030 .

The specific objectives of the S\&M program for Bldg. 3030 are as follows:

1. Ensure adequate containment of contamination,

2. Provide physical safety and security control,

3. Maintain the facility in a manner that will minimize potential hazards to the public, and

4. Provide a mechanism for the identification and compliance with applicable environmental, safety, and health requirements.

The "Postdeactivation S\&M Plan for Building 3030" details the specific S\&M items to be performed and estimates the annual cost of performance. The S\&M cost estimates are based on previous operational costs associated with similar S\&M activities at ORNL.

The S\&M activities associated with Bldg. 3030 include the following types of activities:

- Walkdowns and inspections for structural integrity, safety, radioactive contamination, and hazardous material conditions;

- General housekeeping of the interior and exterior of the building as needed; and

- Maintenance activities required to maintain the security and safety envelope of the facility.

\section{ABNORMAL ACTIVITIES/CONDITIONS}

No Abnormal Activities/Conditions have been identified for Bldg. 3030. 


\section{TURNOVER PACKAGE DOCUMENTATION}

\subsection{ADMINISTRATIVE TURNOVER PACKAGE}

Administrative turnover consists of a collection of administrative documents. This includes procedures, agreements, and other documents not directly related to the physical facility. The level of detail depends on the conditions, requirements, and agreements specific to the facility.

Attachment 4, "Administrative Turnover Package Checklist," reflects the documents required for this facility with respect to administrative turnover. The following sections detail the contents of the applicable sections required for Bldg. 3030.

\subsubsection{Final Deactivation Project Report}

The FDPR is a management summary of the facility deactivation completion and its general status and conditions that demonstrates conformance with DOE's specification of the overall end point. It identifies management actions needed that are not routine. Unresolved issues are also described.

\subsubsection{Regulatory Compliance Documentation}

Regulatory compliance documentation includes the status/compliance of all regulatory commitments; for example, status of compliance with applicable regulations promulgated pursuant to statutes, such as Occupational Safety and Health Administration, RCRA, CERCLA, the National Environmental Policy Act, and the remediation process in the National Contingency Plan.

\subsubsection{Interagency Agreements Documentation}

Interagency agreements documentation includes Interagency Agreements that identify the terms and milestones of agreements pending and entered into by DOE with federal, state, and local agencies and the status of compliance. This includes settlement agreements, administrative or consent orders, and compliance plans to settle outstanding notices of violation.

\subsubsection{Existing Permit Documentation}

Existing permit documentation includes the status of existing permits, including National Pollutant Discharge Elimination System (NPDES), air permits, RCRA, and others associated with the facility.

\subsubsection{Corrective Action Documentation}

Corrective action documentation addresses the status of corrective actions completed and outstanding, from previous audits, inspections, and other similar activities (e.g., Tiger Team, Technical Safety Appraisal, Defense Nuclear Facility Safety Board, regulatory agencies, self assessments, business systems review), including identification of those items that need to reevaluated and reviewed with respect to the facility's surplus condition. 


\subsubsection{Deactivation Locks and Keys}

All deactivation locks and keys for facility access, isolation of electrical components, chaining of valves, and other situations where physical access is to be controlled will be turned over to EM-40 at the time of transfer.

\subsection{TECHNICAL TURNOVER PACKAGE}

Technical turnover consists of a collection of technical documents that describe the facility, its equipment, and the conditions at the completion of all deactivation activities. The level of detail depends on the conditions, requirements, and agreements specific to the facility. Attachment 5, "Technical Turnover Package Checklist," reflects the documents required for this facility with respect to technical turnover. The following sections detail the contents of the applicable sections required for Bldg. 3030.

\subsubsection{Updated Facility Drawings (Arrangement, PID, Loop, Etc.)}

Updated facility drawings include facility, room, and cell arrangement drawings - to the extent they exist. However, except in unique circumstances, as-builts of the deactivated conditions within the facility are not provided. Attachment 6 contains the drawing list for Bldg. 3030. This documentation provides status (including drawings) of the deactivation/safe shutdown (if applicable), and addresses systems, such as the water, sewer, air, electric, gas, process (mechanical and chemical) and fire protection systems.

Table 7. Bldg. 3030 Updated Drawings

\begin{tabular}{|c|c|c|}
\hline Number & Rev. & Title \\
\hline D-37907 & A & Manipulator Cell - Service Piping \& Ventilation - Sections \& Details \\
\hline D-6615 & A & Isotope Process Area - Process Bldg. "C" - Heating \& Exhaust System \\
\hline E-30097 & & Storage Vault - Mechanical \& Electrical - Plans \& Details - Sheet 3 \\
\hline $\begin{array}{l}\text { H203369EG- } \\
\text { 002-D }\end{array}$ & 001 & A/C Elec. Roof Plan A/C Units Isotope Area \\
\hline D-51926 & A & Enclosure Bldgs. 3030 and 3031 - Ventilation \\
\hline D-51926 & & Piping, Htg. \& Vent. \\
\hline
\end{tabular}

\subsection{2 “As Left" Photos of Spaces and Major Equipment}

"As left" photos include descriptions/photos of spaces for which no access is anticipated during S\&M.

\subsubsection{Hazardous Materials Inventory and Survey}

Location of fixed hazardous materials, wastes, and contamination with characterization information. 


\subsubsection{Safeguards and Security Documentation}

Inventory and Safeguards and Security documentation provides for nuclear or other material remaining in the facility for which there is a requirement for accountability or protection from diversion.

\subsubsection{Chemical Substance Inventory and Survey}

The chemical substance inventory and survey inventories chemical and hazardous substances remaining, if any, and contains characterization information.

\subsubsection{Radioactive Materials Inventory and Survey}

The radioactive materials inventory and survey inventories radioactive and fissile material remaining as contamination and includes characterization information.

The final radiological/hazardous materials survey records, final configuration and surveillance and maintenance requirements, available drawings, specifications, procedures, manuals, and unplanned occurrences records applicable to the facility. Attachment 8 contains the radiological survey data.

\subsubsection{Facility Soil, Surface Water, and Groundwater Condition Report}

The Facility Soil, Surface Water, and Groundwater Condition Report describes soil, surface water, and groundwater conditions at the facility, provides all available data, and lists reports that describe those conditions and the nature and extent of contamination therein. This report Also identifies any known assessment requirements.

\subsection{S\&M TURNOVER PACKAGE}

S\&M turnover consists of a collection of documents required to support postdeactivation S\&M activities. The level of detail depends on the S\&M specific to the facility. Attachment 8, "S\&M Turnover Package Checklist," reflects the documents required for this facility with respect to S\&M turnover. The following sections detail the contents of the applicable sections required for Bldg. 3030.

\subsubsection{Postdeactivation S\&M Plan}

This document describes the S\&M plan for the facility after deactivation is complete, up to the initiation of decommissioning. The S\&M activities will be integrated into the decommissioning work and phased out as decommissioning is completed.

\subsubsection{Postdeactivation S\&M Updated Safety Equipment List}

This document describes the safety equipment that will remain in the facility during the postdeactivation S\&M period. 


\title{
8.3.3 Postdeactivation S\&M Procedures
}

Table 8 contains a list of procedures required during the postdeactivation S\&M period. These procedures outline the maintenance activities and special surveillances required to ensure that the facility conditions and safety envelope remain consistent until decommissioning can take place.

Table 8. Bldg. 3030 S\&M Procedures

\begin{tabular}{ll}
\hline \multicolumn{1}{c}{ Number } & \multicolumn{1}{c}{ Procedure Title } \\
\hline IP-1418 & Manipulator Removal, Repair, and Replacement \\
IP-1313, Rev.2 & Local and Central Ventilation System HEPA Filter Replacement \\
\hline
\end{tabular}

\section{ASSOCIATED LITERATURE}

\author{
Document \\ Number \\ Draft \\ Facility Deactivation End Points Handbook; Volume 1: Method and \\ Examples \\ Draft Facility Deactivation End Points Handbook; Volume 2: Deactivation \\ Practices \\ DOE/EM-0246 Decommissioning Resource Manual. August 1995 \\ ORNL/ER-249/R2 Martin Marietta Environmental Restoration Program; Work Plan for the \\ Isotopes Facilities Deactivation Project at Oak Ridge National Laboratory, \\ August 1995 \\ Oak Ridge National Laboratory; Local Emergency Manual, Isotope Area, \\ Revision 94-1, January 1994
}

\section{ATTACHMENTS}

1. Bldg. 3030 Floor Plan

8. Bldg. 3030 Predeactivation Facility Photographs

9. Bldg. 3030 Postdeactivation Facility Photographs

10. Administrative Turnover Package Checklist

11. Technical Turnover Package Checklist

12. Bldg. 3030 Drawing List

13. Bldg. 3030 Radiological Survey Data

14. S\&M Turnover Package Checklist 
ATTACHMENT 1

BLDG. 3030

FLOOR PLAN 

ORNL DWG 97C-250

\section{Building $\mathbf{3 0 3 0}$}

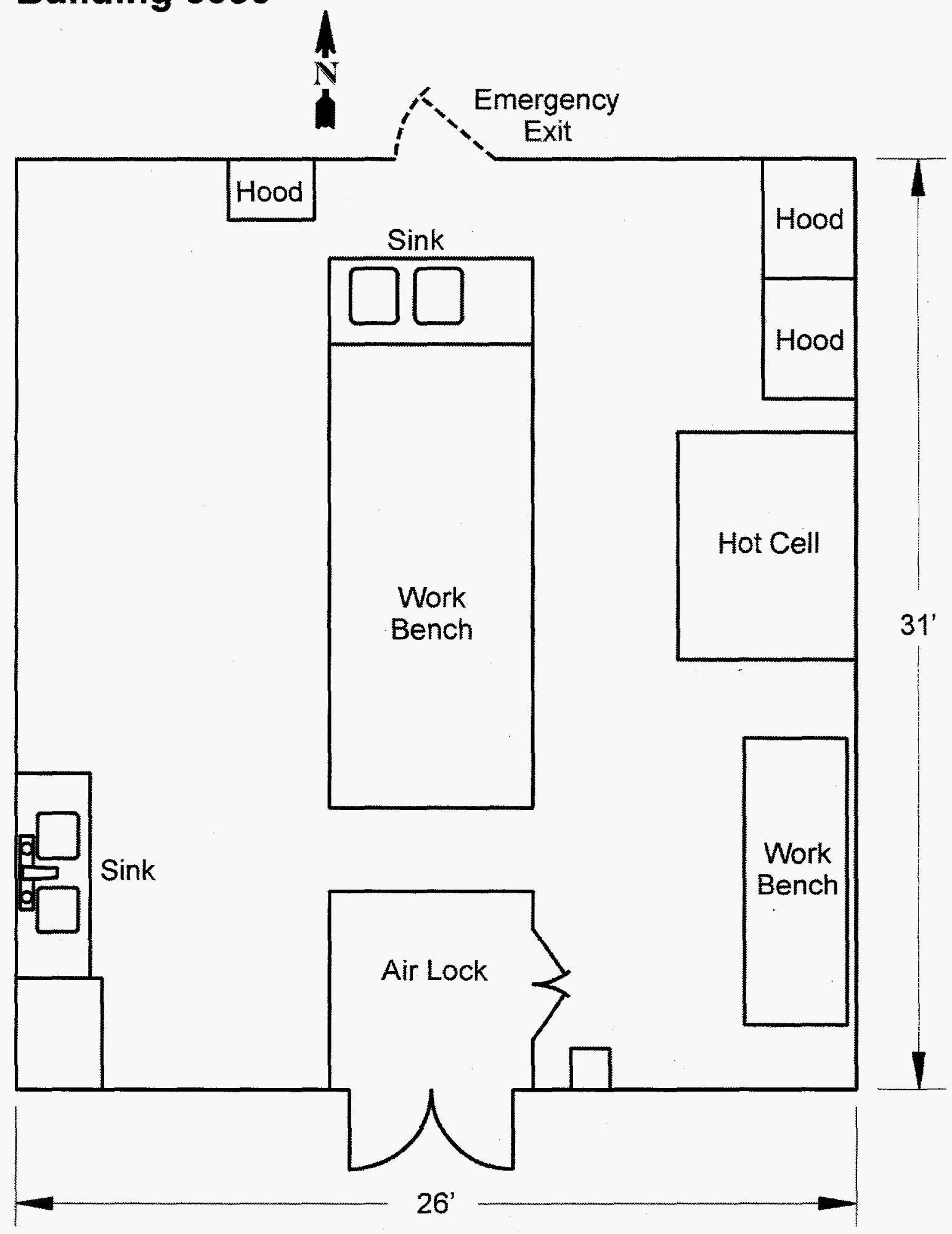



ATTACHMENT 2

BLDG. 3030

PREDEACTIVATION FACILITY PHOTOGRAPHS 



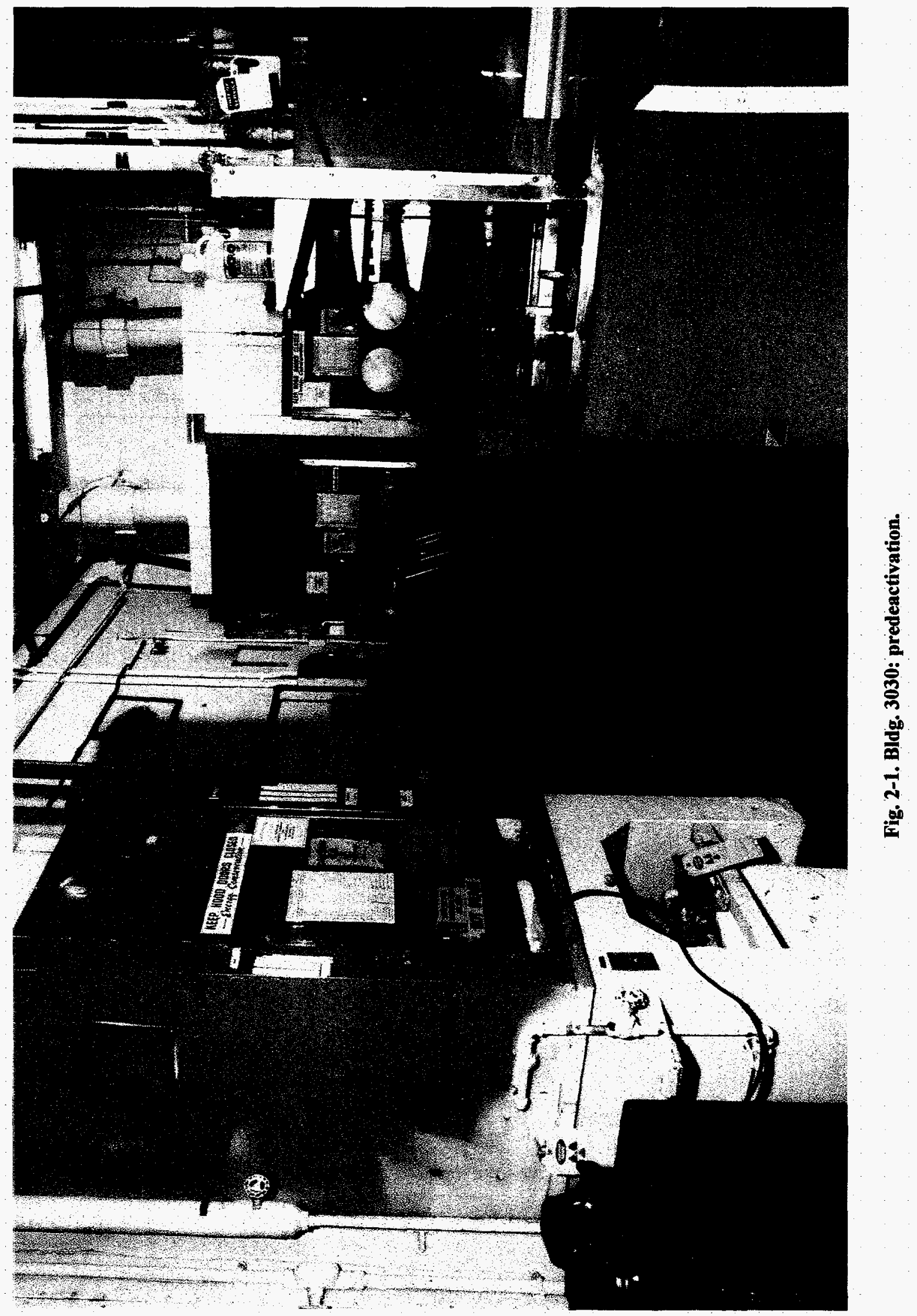




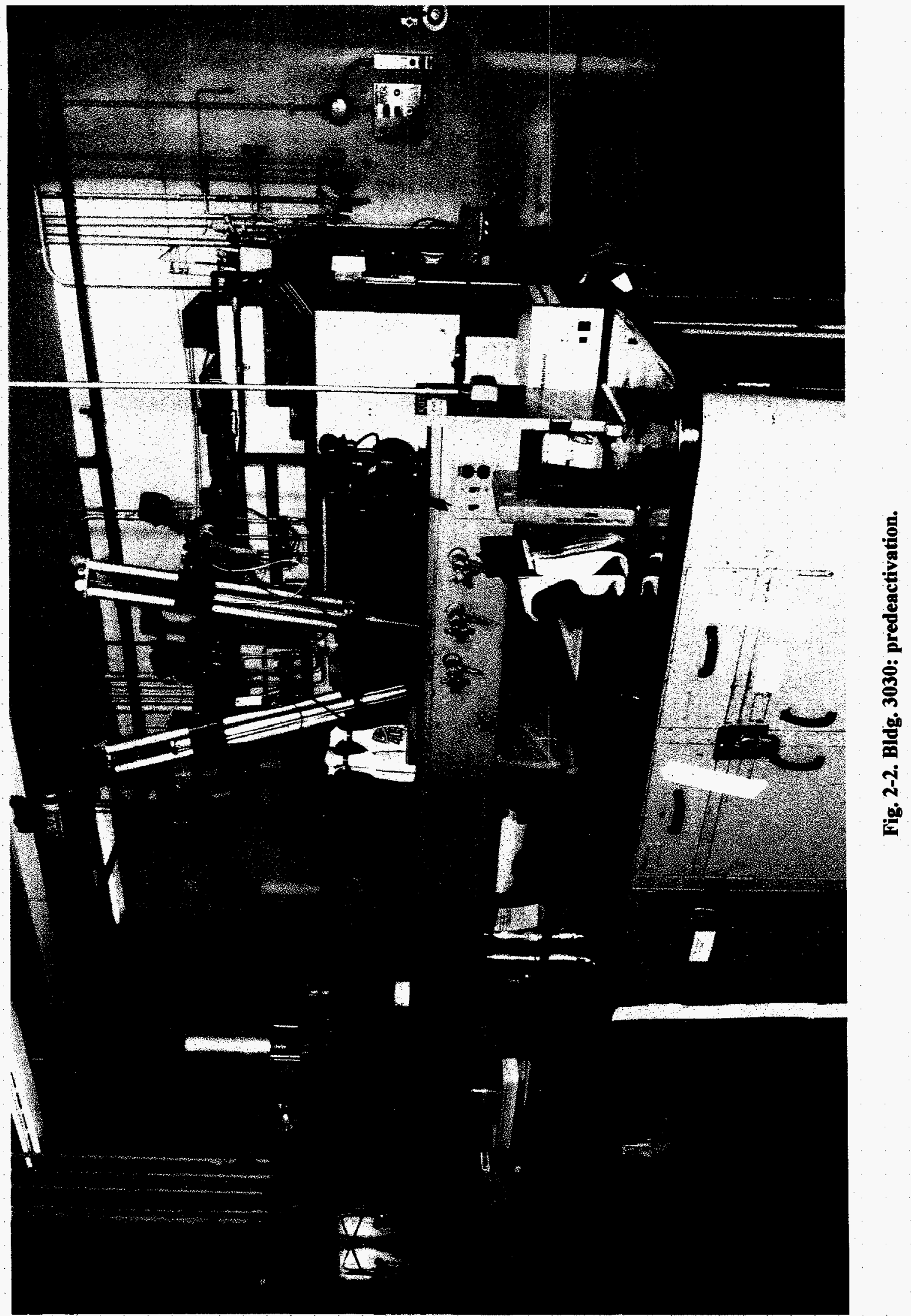


ATTACHMENT 3

BLDG. 3030

POSTDEACTIVATION FACILITY PHOTOGRAPHS 



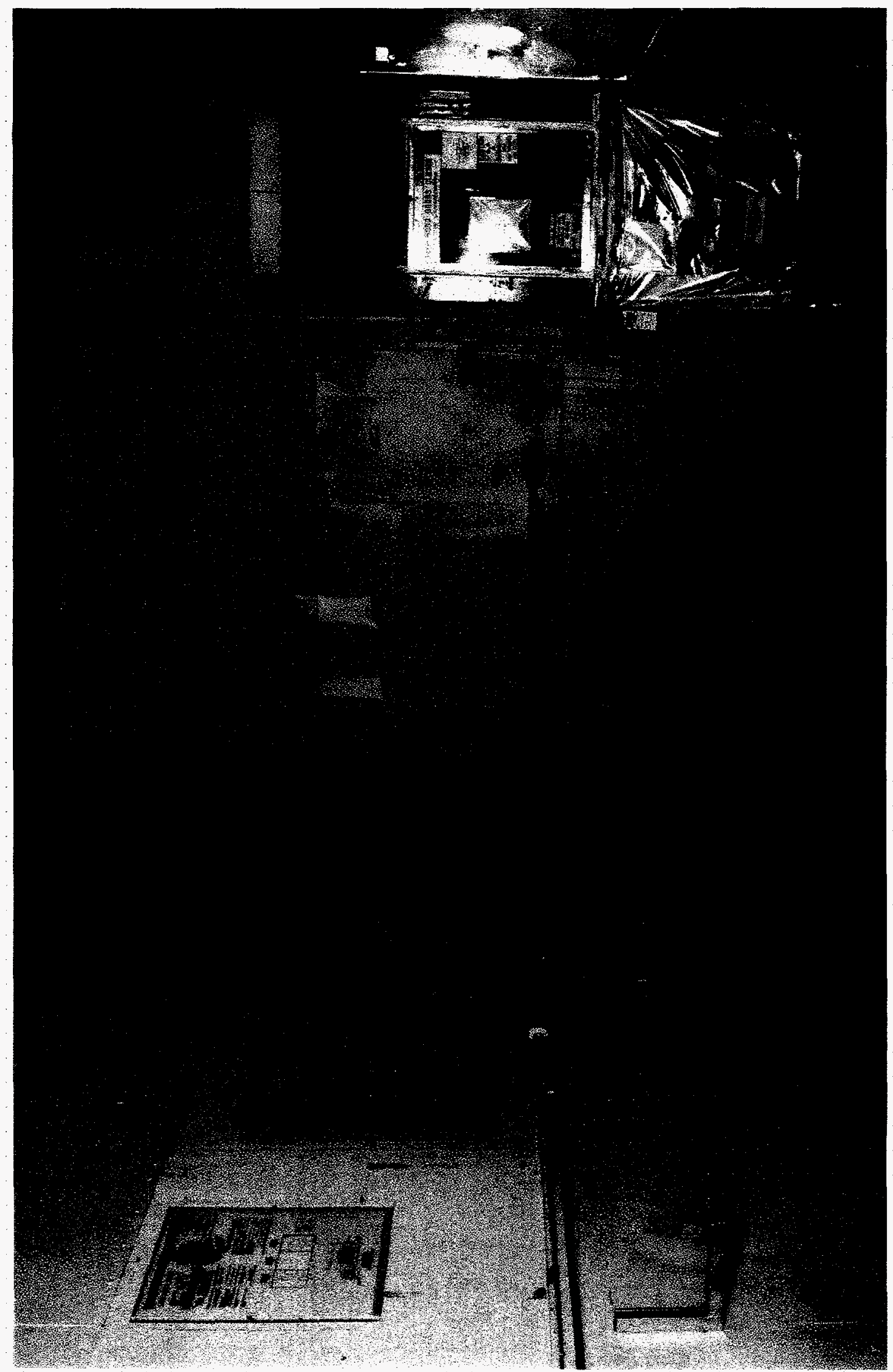




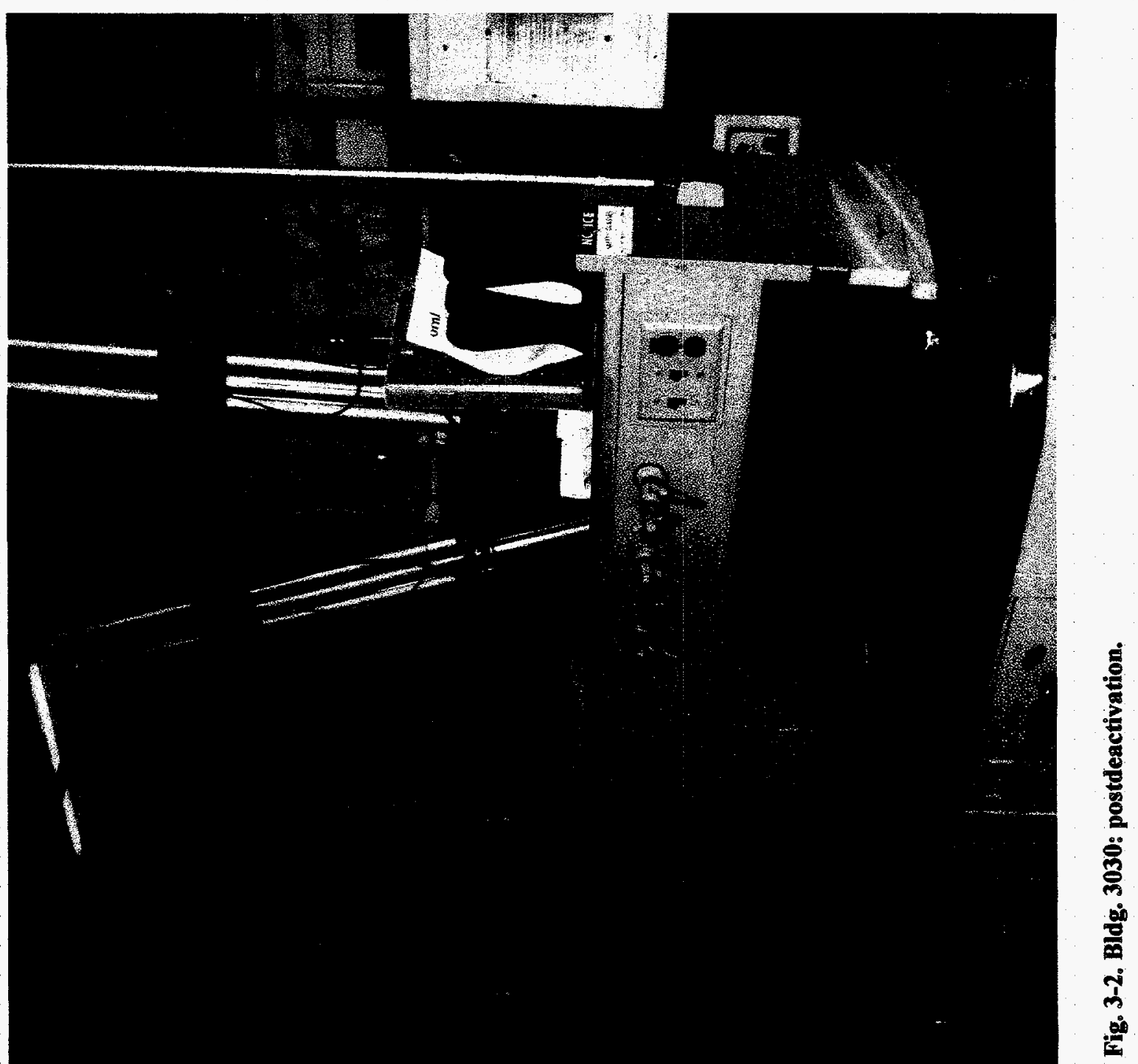


ATTACHMENT 4

ADMINISTRATIVE TURNOVER

PACKAGE CHECKLIST 



\begin{tabular}{cll}
\hline Item Number & \multicolumn{1}{c}{ Document } & Applicable ? \\
\hline 1 & Final Deactivation Project Report & Yes \\
2 & Emergency Response Plan & No \\
3 & Safety Documentation (Category III or greater) & No \\
4 & Regulatory Compliance Documentation & No \\
5 & Interagency Agreements Documentation & No \\
6 & Existing Permit Documentation & No \\
7 & Corrective Action Documentation & No \\
8 & Postdeactivation Punchlist & No \\
9 & Deactivation Locks and Keys & Yes \\
\hline
\end{tabular}



ATTACHMENT 5

TECHNICAL TURNOVER

PACKAGE CHECKLIST 



\section{$5-3$}

Technical Turnover Package Checklist

\begin{tabular}{clc}
\hline Item Number & \multicolumn{1}{c}{ Document } & Applicable ? \\
\hline 1 & End Point Determination Report & No \\
2 & End Points Completion Report & No \\
3 & End Point Technical Information & No \\
4 & Deactivation Work Plans & No \\
5 & Updated Facility Drawings (arrangement, PID, Loop, etc.) & Yes \\
6 & "As Left" Photos of Spaces and Major Equipment & Yes \\
7 & Hazardous Material Inventory and Survey & No \\
8 & Safeguards and Security Documentation & No \\
9 & Chemical Substance Inventory and Survey & No \\
10 & Radioactive Materials Inventory and Survey & No \\
11 & Facility Soil, Surface Water, and Groundwater Condition & Yes \\
\hline
\end{tabular}



ATTACHMENT 6

BLDG. 3030

DRAWING LIST 

Bldg. 3030 Drawing List

\begin{tabular}{|c|c|c|}
\hline Document Number & Revision & Title \\
\hline C3E-020366-A001 & & Reroof Bldgs. 303, 3031, 3118 - site access plan and drawing index \\
\hline D-18749 & & Manip cell elec plan \& sects \\
\hline D-19819 & & Manipulator cell - service piping, drains \& exhaust \\
\hline D-19820 & & Manipulator Cell - service piping \& exhaust detail \\
\hline D-20525 & & Alterations existing cell top view front elec sect \\
\hline D-20526 & & Alterations existing cell plot plan sect elev det \\
\hline D-20527 & & Roof plan, sects \& front elev. \\
\hline D-20567 & & Roof plan, sects \& front elev. \\
\hline D-20568 & & Plot plan, sect. elev. \& dets \\
\hline D-20569 & & 67 lead door dets \\
\hline D-20570 & & Misc dets sht 1 \\
\hline D-20571 & & Misc dets sht 2 \\
\hline D-43620 & & Driveway \& curb alteration $\&$ new man hole cover \\
\hline D-51920 & & Elec \& fire det plans \\
\hline D-51926 & & Enclosure Bldgs. 3030 and 3031 - ventilation \\
\hline D-52252 & & Foundation plan, sect \& dets \\
\hline D-52253 & & Floor plan \& steel framing dets \\
\hline D-52254 & & wall sects $\&$ door sched \\
\hline D-5545 & & $20 \mathrm{ft}$ hot barricades foundation plant \& det \\
\hline D-5546 & & $20 \mathrm{ft}$ hot barricades structural plan \& elev \\
\hline D-5547 & & $20 \mathrm{ft}$ hot barricades lead wall framing dets \\
\hline D-5556 & & Machine barricade plan \& elev. \\
\hline D-5557 & & Machine barricade sects \& dets \\
\hline D-5709 & & Mach barricade hoods sect $\&$ dets \\
\hline D-5744 & & $20 \mathrm{ft}$ hot barricades exh hood \\
\hline D-6640 & & D building serv piping plan, sect $\&$ dets \\
\hline E20366EF-003-D & & South wall encl elec fire det plans \\
\hline E20378D-001-D & & $440 \mathrm{v}$ elec feeder new $440 \mathrm{v}$ isotope area distr plot $\mathrm{pl}$ \\
\hline E3E-20375-D003 & & Fire alarm plans \\
\hline E-5622 & & Hot sink tables items $22-28 \& 33-\mathrm{A}$ \\
\hline E-5730 & & Process bldg. exhaust hoods \\
\hline H20366EG-001-D & & $\mathrm{A} / \mathrm{C}$ elec struc roof plan dets $\mathrm{A} / \mathrm{C}$ units iso area \\
\hline M20366EL-001-D & & Cell window ext assy det \\
\hline
\end{tabular}


6-4

Bldg. 3030 Drawing List (continued)

Document Number

ORNL/ENG/SR-221

ORNL/ENG/SR-221 R1

S20366EF-001-D

S20366EF-002-D

S3E-020366-B012

S3E-020366-B013

X1989-0032-0003-008

X1991-0031-001

X1991-0031-0003-006

X-RAP-0300-0

\section{Revision}

Title

Safety review reroof Bldgs. 3031, 3031, \& 3118

Safety review reroof Bldgs. 3031, 3031, \& 3118

South wall encl steel framing plant dets

South wall encl steel framing exh dets

Reroof Bldgs. 3030, 3031, 3118 - roof plant, sections \& details

Reroof Bldgs. 3030, 3031, 3118 - sections \& details

Isotope processing facility functional criteria

Memo: checking roofs for radiation contamination

Identification of bulk samples for asbestos content (asbestos survey)

Risk assessment/plan for reroof Bldgs. 3030, 3031, \& 3118 


\section{ATTACHMENT 7}

BLDG. 3030

RADIOLOGICAL SURVEY DATA 


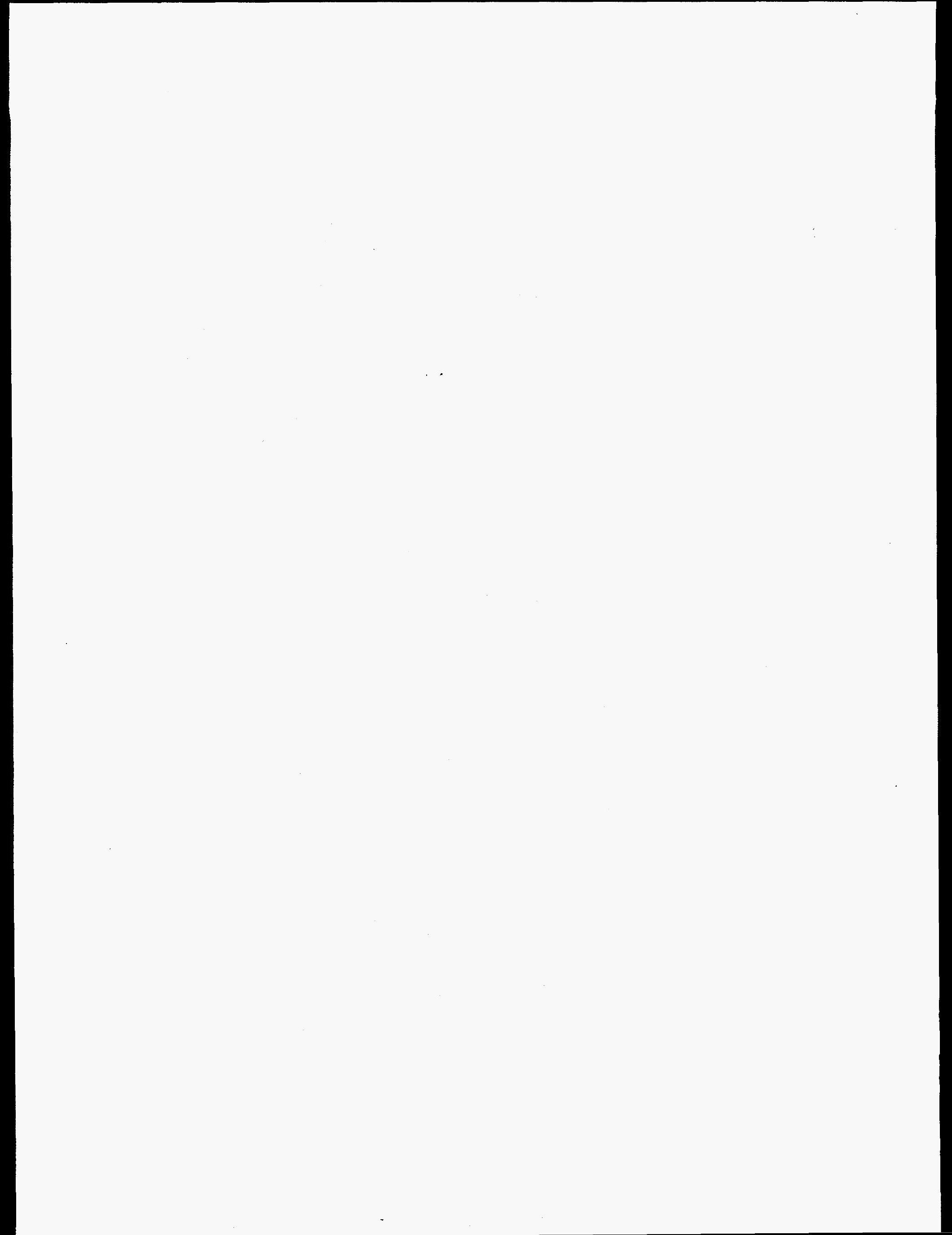


ORNL Radiological Survey Data

Survey Number: 3038-96-1885

3038 Field Office

Date: $8 / 29 / 96$

Time: 10:15

Surveyor Badge Number: 626079 DRoutine Survey RWP Number: 3038-96-0040A

Building: 3030,3118 Specific Location: Bldg 3030 hot cell and 3118 @ rear cell door

Description:

Enter 3030 hot cell via 3118 to remove waste, replace rings that hold bottom part of the manipulator boot an and do radiological survey.

Instruments Used and Calibration Due Date:

$\begin{array}{llllll}\text { CTB-047 } & 3 / 1 / 97 & 3038-11 & 2 / 11 / 97 & 3038-3 \mathrm{P} & 3 / 26 / 97\end{array}$

General Description of Radiological Conditions: From oreurious survex

Maximum loose contamination: $350,000 \mathrm{dpm} 700 \mathrm{~cm}$ sq beta-gamma. Maximum fixed contamination: 1 R/hr beta-

gamma. The average whaie body dose is $42.5 \mathrm{mR} / \mathrm{hr}$ beta-gamma. The smear results from the surver performed are listed

gamma. The average whoie body dose is $42.5 \mathrm{mR} / \mathrm{hr}$ beta-gamma. The smear results from the survey performed are listed
below.

Division or Group Needing the Survey:

CT

Person-hours spent on the survey:

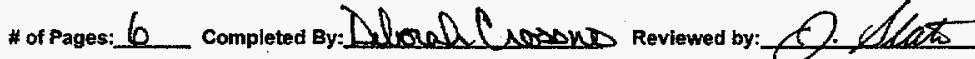
Date: $1.29 \cdot 97$

\begin{tabular}{|c|c|c|c|c|c|c|c|c|c|c|c|}
\hline \multicolumn{12}{|c|}{ Smear Results (dpm/100 cm unless noted) } \\
\hline $\begin{array}{l}\text { Simear } \\
\text { Number }\end{array}$ & $\alpha$ & $\beta$ & Location & Simear & $\alpha$ & $\beta$ & Location & $\begin{array}{c}\text { Simetar } \\
\text { Number } \\
\end{array}$ & $\alpha$ & $\beta$ & Location \\
\hline 1 & NC & \multirow{2}{*}{$\begin{array}{r}21.0 \\
\mathrm{mPhr}\end{array}$} & see mep & 2 & NG & $4.5 \mathrm{mP} / \mathrm{hr}$ & Seat map & 3 & NC) & \multirow{2}{*}{\multicolumn{2}{|c|}{$80,000 /$ see men }} \\
\hline & & & & & & & & & & & \\
\hline 4 & $\mathrm{NC}$ & 250,000 & ses men & 5) & NC: & 300,000 & Seet map & 6 & $\mathrm{NC}$ & 100,000 & 500 meso \\
\hline 7 & $\mathrm{NC}$ & 230,000 & Sime nam & 8 & NC & $3.5 \mathrm{mR} / \mathrm{hr}$ & See nxop & 9 & NC & 200,000 & sese mase \\
\hline 10 & NC & 1,421 & Seat nup & 11 & $\mathrm{NC}$ & 6,433 & see map & 12 & NC & 6,265 & sesending \\
\hline 13 & $\mathrm{NC}$ & 100,000 & ses meap & 14 & NC: & 100,000 & sea mepp. & & & & \\
\hline
\end{tabular}

Description Cell entry

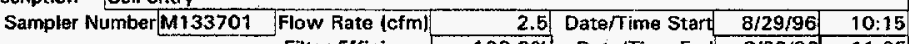

\begin{tabular}{rr|r|r|r|}
\hline Filter Efficiency & $100.0 \%$ & Date/Time End & $8 / 29 / 96$ & $11: 05$ \\
\hline
\end{tabular}

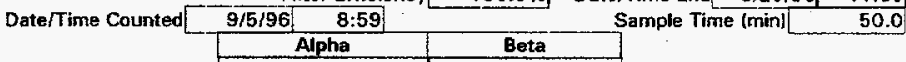

\begin{tabular}{|c|c|c|c|}
\hline & Alpha & Beta & \\
\hline Counter ID & CTA-041 & CTB-047 & AlR \\
\hline Counter Efficiency & $42.5 \%$ & $14.4 \%$ & \\
\hline Backgraund Counts & 1 & 50 & \\
\hline Bkgd Count Time (min) & 5 & 5 & SAMPLE \\
\hline Gross Sample Counts & 4 & 24 & \\
\hline Sample Count Time (min) & 1 & 1 & \\
\hline Sample OPM & 8.9 & 97.2 & \\
\hline Air Concentration (uCi/mi) & $1.14 \mathrm{E}-12$ & $1.24 \mathrm{E}-11$ & First Count Factor \\
\hline Min. Det. Conc. (uCi/ml) & $1.29 \mathrm{E}-12$ & $1.25 \mathrm{E}-11$ & Tas? \\
\hline
\end{tabular}




\section{Deberan crossno}

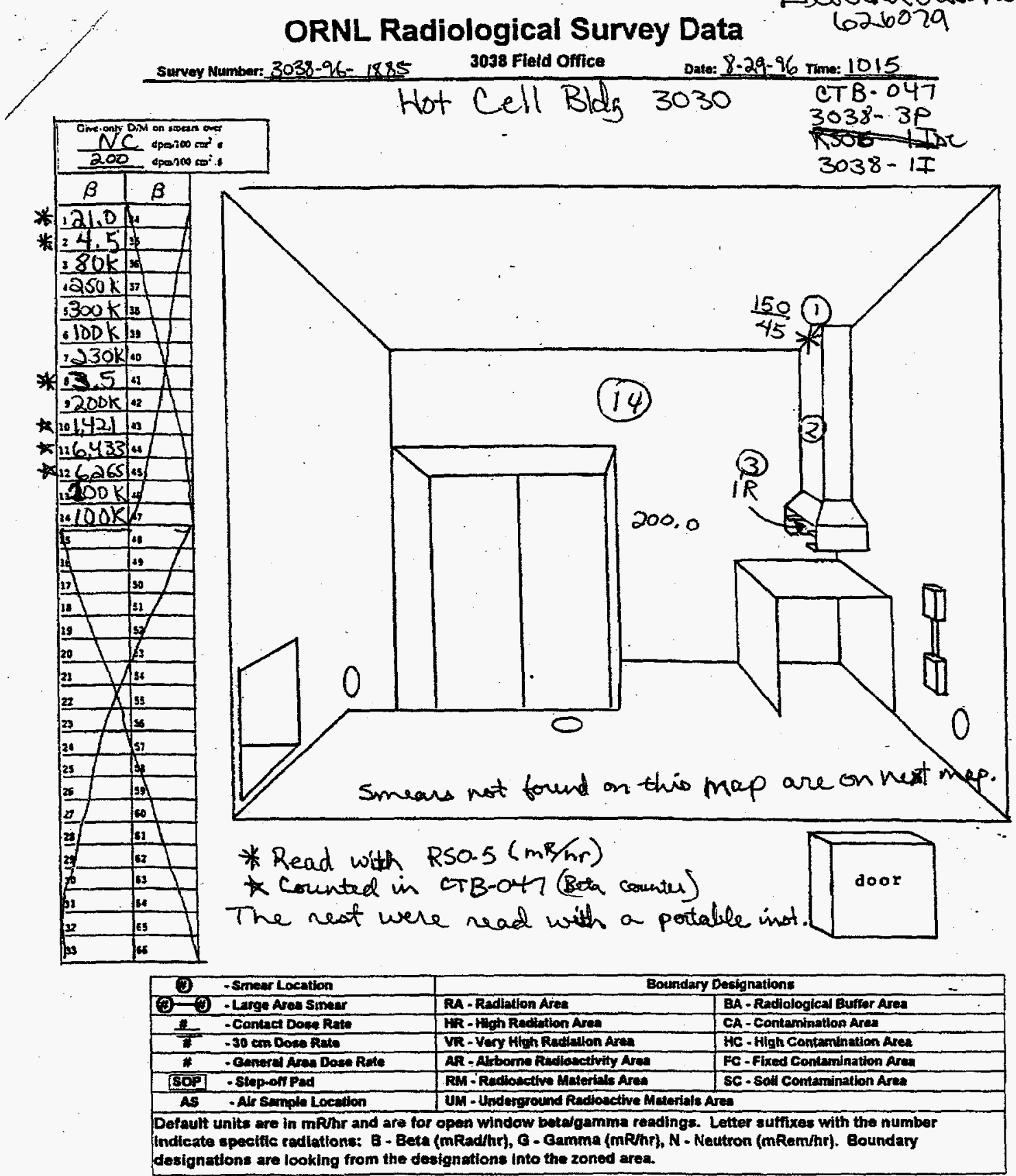




\section{ORNL Radiological Survey Data}

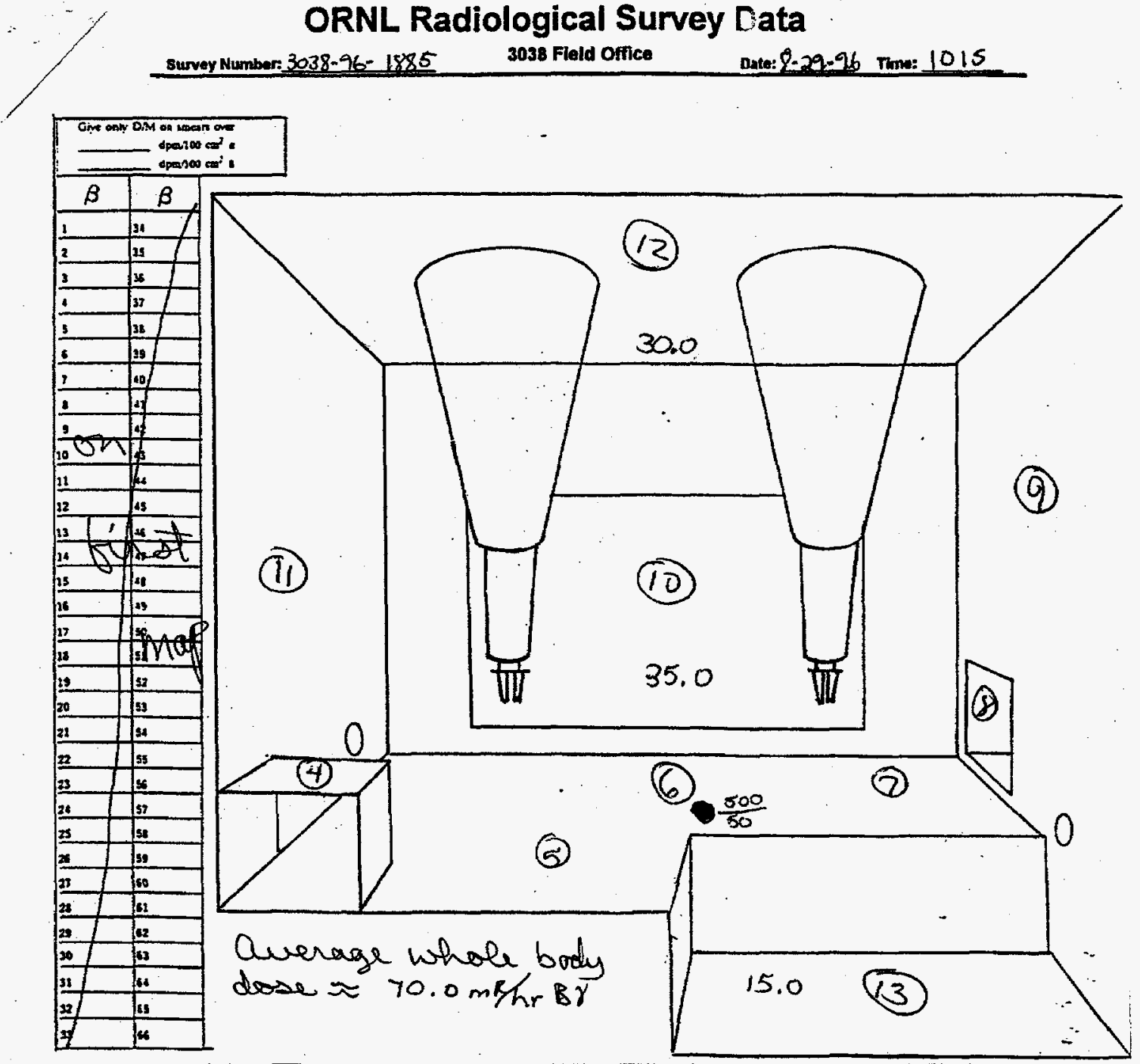

\begin{tabular}{|c|c|c|c|}
\hline 3 & - smear Lacation & \multicolumn{2}{|c|}{ Boundery Designations } \\
\hline & - Large Ares Smear & RA - Redialion Area & Ba-Radiological Bufler Aves \\
\hline 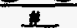 & - Contaet Dacen Rato & MR - High Radiation Area & CA - Contemination Ares \\
\hline 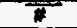 & $.30 \mathrm{~cm}$ Dose Rato & VR - Very High Rudtation Ares & HC - Migh Contunination Area \\
\hline 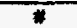 & - General Area Dose Rate & AR - Arborme Redionctivity Aren & FC - Ftxed Contendintion Ares \\
\hline [SOP] & - Step-off Pad & 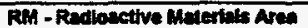 & Sc-Soll Contamination Area \\
\hline As & - Air Semple Location & \multicolumn{2}{|c|}{ UM - Underground Radionctive Materials Ares } \\
\hline
\end{tabular}

Default units are in mR/hr and are for open window beta/gamma feadings. Letter sufixes with the number indicoto speciffic radiationa: B - Beta (mRad/hr), G - Gamms (mR/hr), N - Neutron (mRem/hr). Boundary designations are fooking from the designations into the zoned area. 


\section{ORNL Radiological Survey Data}

Survey Number: 3038-96-1880 3038 Field Office

Date: 8/26/96

Time: 9:00

Surveyor Badge Number:

IRoutine Survey RWP Number: 3038-95-0029

Bullding: 3030

Specific Location: On log of hot cell

Description:

Surve to detemine contaninationiratiation levels prior to upooming work.

Instruments Used and Calibration Due Date:

$$
\text { CTB } 84 \text { ? }
$$

$$
31199 ?
$$

$3038-11 \quad 2111997$

General Description of Radiological Conditions:

The highest smear was 9,975 dpin $100 \mathrm{~cm}$ sq beta-gamma. The highest dose rale was $30000 \mathrm{~m}$ Rthr beta-gamma at contact with the back of the cell where it imeets the wall and $20.0 \mathrm{mR} / \mathrm{hr}$ at $30 \mathrm{~cm}$. After the manipulator work leflover lead was used to shield the $300 \mathrm{mR} / \mathrm{hr}$ spot down to $<5.0 \mathrm{mR} / \mathrm{hr}$ at $30 \mathrm{~cm}$. The laverage whole body dose after mis is $-1.1 \mathrm{mR} / \mathrm{hr}$ beta-gamma. Then the top of the cell was posted as a contamination area $8129 / 96$.

Division or Group Needing the Survey: CT Person-hours spent on the survey:

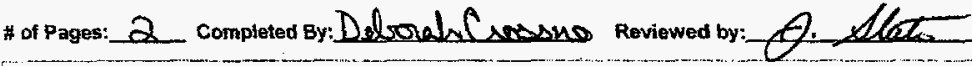

\begin{tabular}{|c|c|c|c|c|c|c|c|c|c|c|c|}
\hline \multicolumn{12}{|c|}{ Smear Results (dpm/100 $\mathrm{cm}^{2}$ unless noted) } \\
\hline $\begin{array}{l}\text { Smaarar } \\
\text { Number }\end{array}$ & $\alpha$ & $\beta$ & Location & $\begin{array}{l}\text { Smatar } \\
\text { Number }\end{array}$ & $\alpha$ & $\beta$ & Location & $\begin{array}{l}\text { Sravear } \\
\text { Nurnteor }\end{array}$ & $\alpha$ & $\beta$ & Location \\
\hline & NC & $<200$ & see mat & 2 & $\mathrm{NC}$ & $<200$ & Set inas & 3 & NC & 1,309 & See map \\
\hline 4 & NCे & 5,068 & $\operatorname{sen}$ map & 5 & NC & 4,186 & See mep & 6 & NC) & $<200$ & See inap \\
\hline & NC) & 273 & Sea may & 8 & NC: & 9,975 & Seo map & 9 & $\mathrm{NC}$ & 553 & Seo mas \\
\hline 10 & Net & 329 & Sos mas & 11 & NC & 247 & Ses mas & & & & \\
\hline
\end{tabular}
Date: $12-3-96$ 


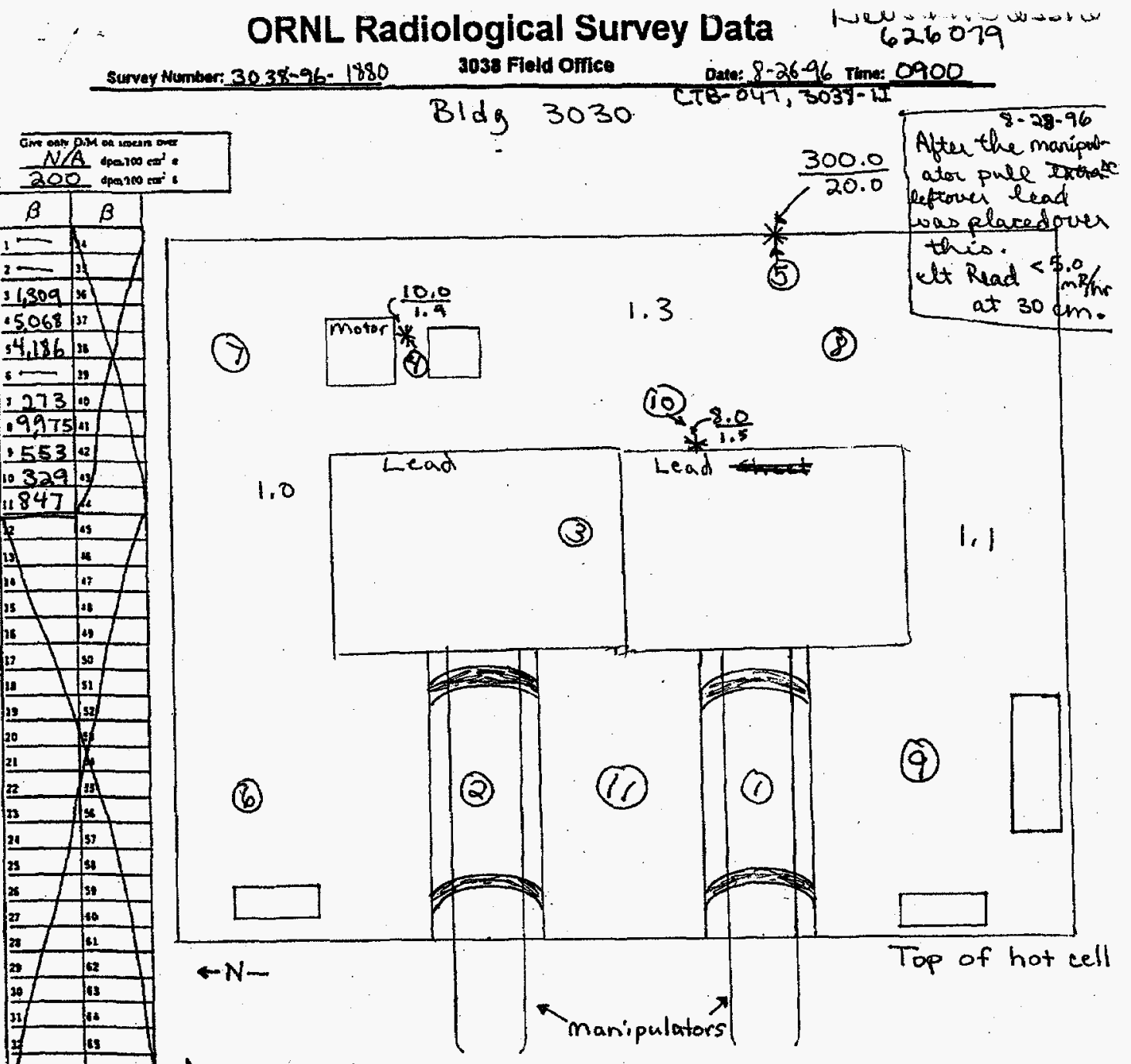

Average whole body dese $=1.1 \mathrm{mR} / \mathrm{hr}$ BY on 8-28-96.

\begin{tabular}{|c|c|c|c|}
\hline 0 & - Simear Location & \multicolumn{2}{|c|}{ Boundary Deaignaflons } \\
\hline $0-3$ & - Large Ares Smear & RA-Radintion Ares & BA - Rediologient Bufrer Area \\
\hline i & - Contect Dose Rate & WR - High Radietion Area & CA. Contanination Ares \\
\hline \# & $-30 \mathrm{~cm}$ Dose fate & VR - Very Hogh Rodiation Aroe & HC-Hlgh Comenniandion Aren \\
\hline 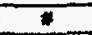 & - Cenerat Ares Dose Rate & AR - Alboun fodloactriky Ares & FC-Fixed Compinhatton Arean \\
\hline BOP] & - Elep-ofl Pad & Fin - Rediosctive Menorita Area & SC-Soll Contuminution Area \\
\hline As & - Alr semple Location & \multicolumn{2}{|c|}{ UM - Underground Radlosective Materialis Ares } \\
\hline \multicolumn{4}{|c|}{ 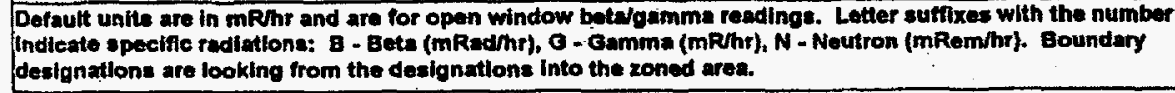 } \\
\hline
\end{tabular}

The top of this cell was posted as a Paga: 2 contamination area aftes the manipulator pull. 


\section{ORNL Radiological Survey Data}

Survey Number: 3038-95:1073

3038 Field Office

Date: $97 / 95$

Time: 09:00

Surveyor Badge Number: __ 740958

Routine Surver RWP Number: 3038-95-0015

Bullding: 3030

Specific Location: Roof and Attic

Description:

Personnel to enter roof and attic for inspertions.

instruments Used and Calibration Due Date:

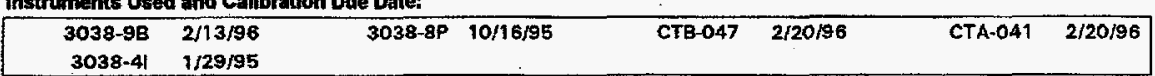

Genoral Description of Radiological Conditions:

Max. beta-gamme contamination levels wera 7000 dpm $/ 100 \mathrm{~cm} 2$. No glpha contamination was precent. Max. Rad. field was $150 \mathrm{mr} / \mathrm{hr}$ at contact. The general working bkg was < $1 \mathrm{mr} / \mathrm{hr}$.

Porsonthours apent on the surver:

* of Pages: 5 completed By:balx

Reviewed by: Date: $9-13-95$ 


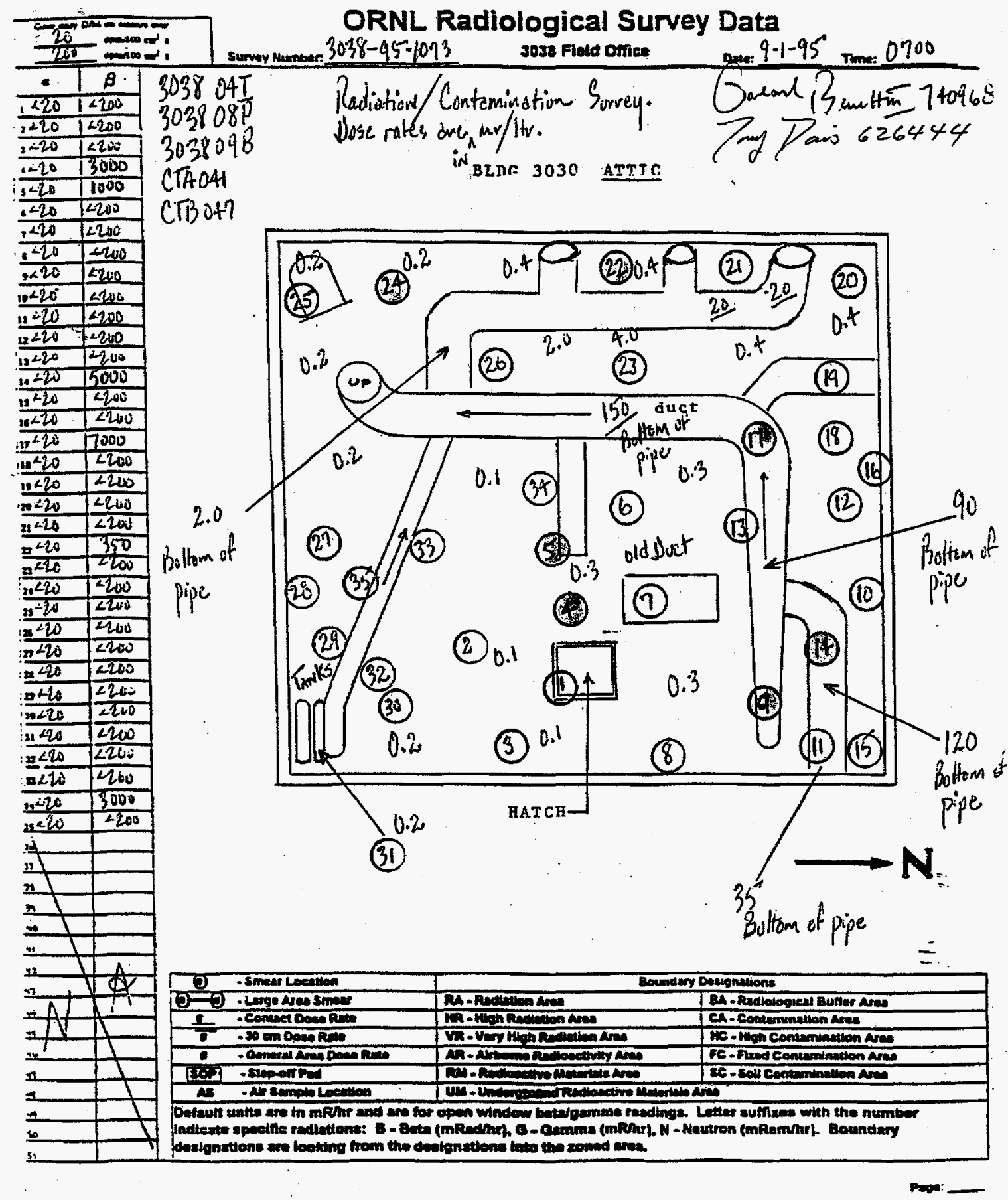




\title{
ORNL Radiological Survey Data
}

Survey Number: 3038-94-0047

\author{
3038 Field Office
}

Date: $9 / 15 / 94$

Time: 09:00

Surveyor Badge Number: $\mathbf{3 2 7 2 1}$

Doutine Survey RWP Number: 102130

Building: 3030

Spocific Location: Hoods

Description:

Final smaar results before deconners paint the strippable coating in all three hoods.

Instruments Used and Calibration Due Date:

$$
\text { CTB-047 2/23/95 }
$$

General Description of Radiological Conditions:

See attached maps for the final smear results. The hoods were peinted today with the yellow strippable coating.

Division of Group Nosding the Survay: $\mathrm{CT}$

Person-hours spent on the survey:

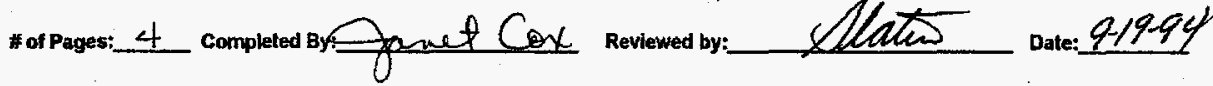




\section{ORNL Radiological Survey Data}

Survey Number: ORNL-94-0027 3038 Field Office

Date: $919 / 94$ Time: 1440 CRNL-94-003i

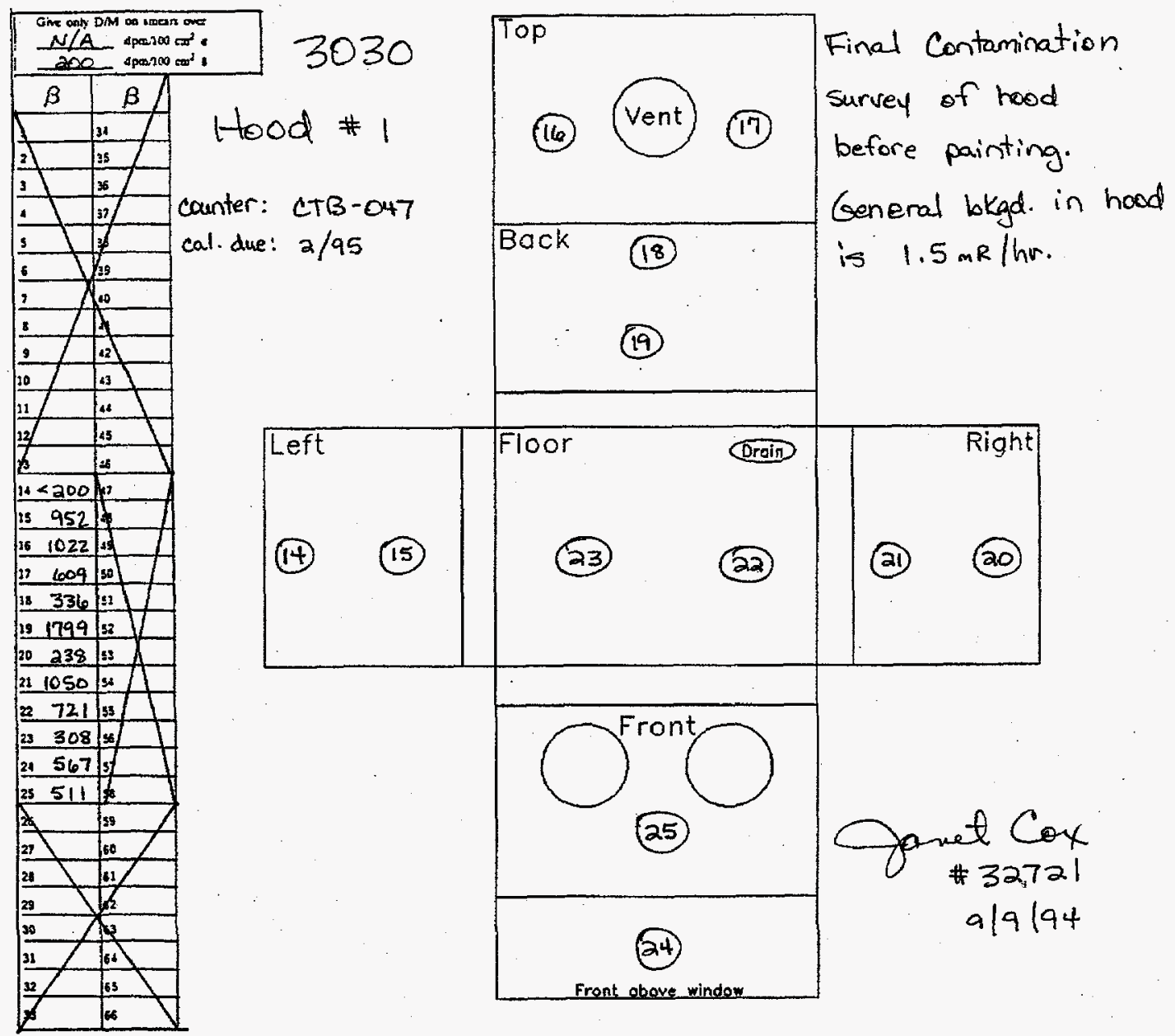

\begin{tabular}{|c|c|}
\hline 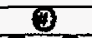 & - Smear Location \\
\hline 90 & - Large Ares smear \\
\hline \# & - Contact Dase Rats \\
\hline$\pi$ & - 30 cm Dose Rale \\
\hline 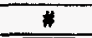 & - Ceneral Area Dose Rate \\
\hline SOP] & - Step-off Ped \\
\hline As & - Alr Sample Location \\
\hline
\end{tabular}

\begin{tabular}{|l|}
\hline RA - Radiation Area \\
\hline HR - Mgh Radiation Avea \\
\hline VR - Very High Radiation Area \\
\hline
\end{tabular}

VR - Very High Radiation Area

AR - Airbome Radioectlvity Area

RH - Radlosctive Matertals Ares

UM - Underground Radioactive Materials Area

Default units are in $\mathrm{mPh}$ and are for open window beta/gamma readings. Letter suffixes with the number

designations are looking from the designations Into the zoned area. 
ORNL Radiological Survey Data

Survey Number: $3038-94-0046$

3038 Field Office

Date: 9 l14 lay Time: 1345

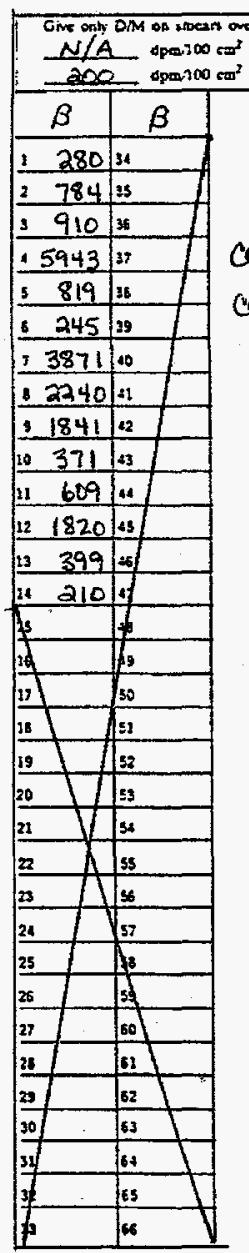

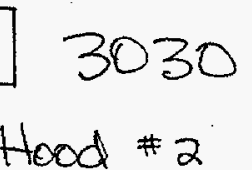

Hood $\# 2$

counter: CTB-047

cal. due: $2 / 95$

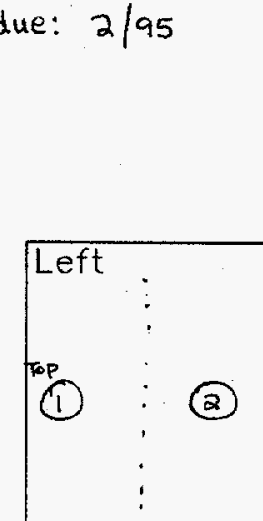

Top

(8)
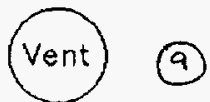

Back

(3)

(4)

(5)

Floor

(11)

(10)

(7)

Final Contamination

survey in hood before painting. General

background in hood is 6. $0 \mathrm{mR} / \mathrm{hr}$.

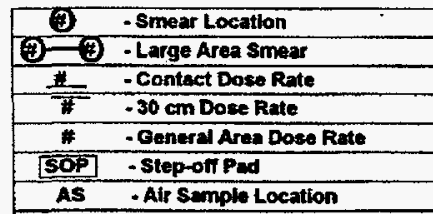

Boundary Designatlong

$D_{\text {met }} \operatorname{cox}$

\#32721

(12)

$9.9194 x$

9114194

BA - Radiological Butfer Area VR - Very High Radiation Area AR - Airborme Radioactivity Area

RM - Radioactive Materials Aves

CA - Contamination Area

CA-Contamination Area FC - Ftred Contamingtion Area SC - Soil Contamination Area

Default units are in mithr and are for open window betalgamma readings. Letter suffixes with the number indicate specific radiations: B - Beta (mRad/hr), G - Gamma (mR/hr), N - Neutron (mRem/hr). Boundary designations are looking from the designations into the zoned area. 


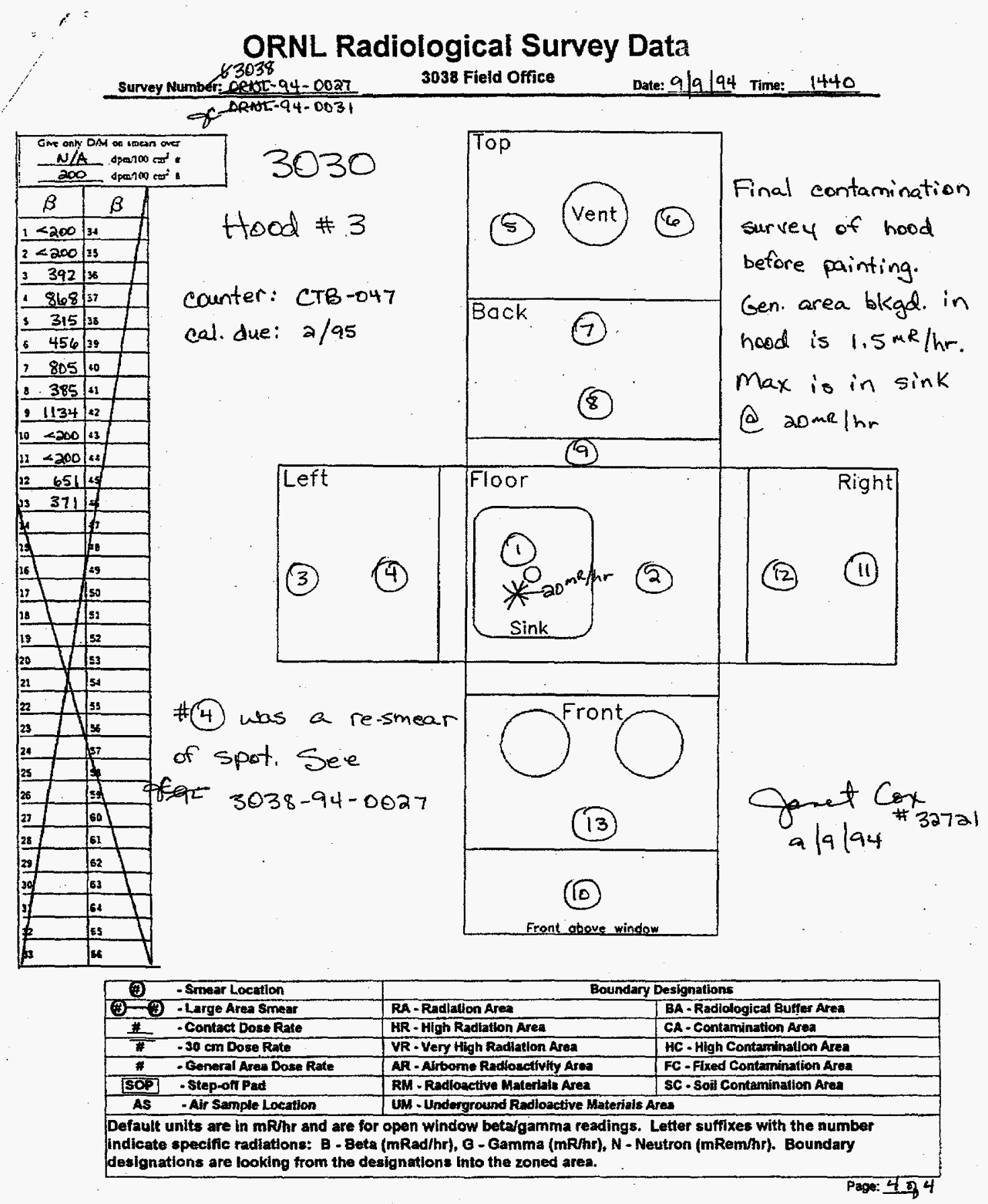




\section{ORNL Radiological Survey Data}

Survey Number: 3038-96-1743

3038 Field Office

Date: $8 / 16 / 96$

Time: 10:10

Surveyor Badge Number: . 626079

DRoutine Survey RWP Number: NAA

Building: 3030

Specific Location: Roof

Description:

Bi-annual radiation survey.

Instruments Used and Calibration Due Date:

$$
3038-41 \quad 11 / 25196
$$

General Description of Radiological Conditions:

The average whale body dose is $-0.24 \mathrm{mR} h$ r bela-garnma. The highest background reading was $0.8 \mathrm{mR} / \mathrm{h}$ on the northeast side near buliding 3029 . The

fiter bank read about the same as the background.

Division or Group Needing the Survey:

CT

Person-hours spent on the survey:

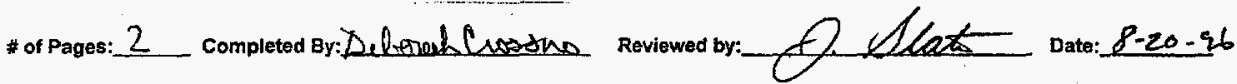


ORNL Radiological Survey Data 62.6079 survey Number: $3638-96-1743 \quad 3038$ Field Ofice Date: $8.15-96$ Time: 1010

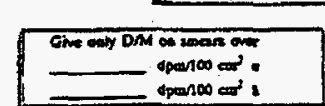
$3038-41$
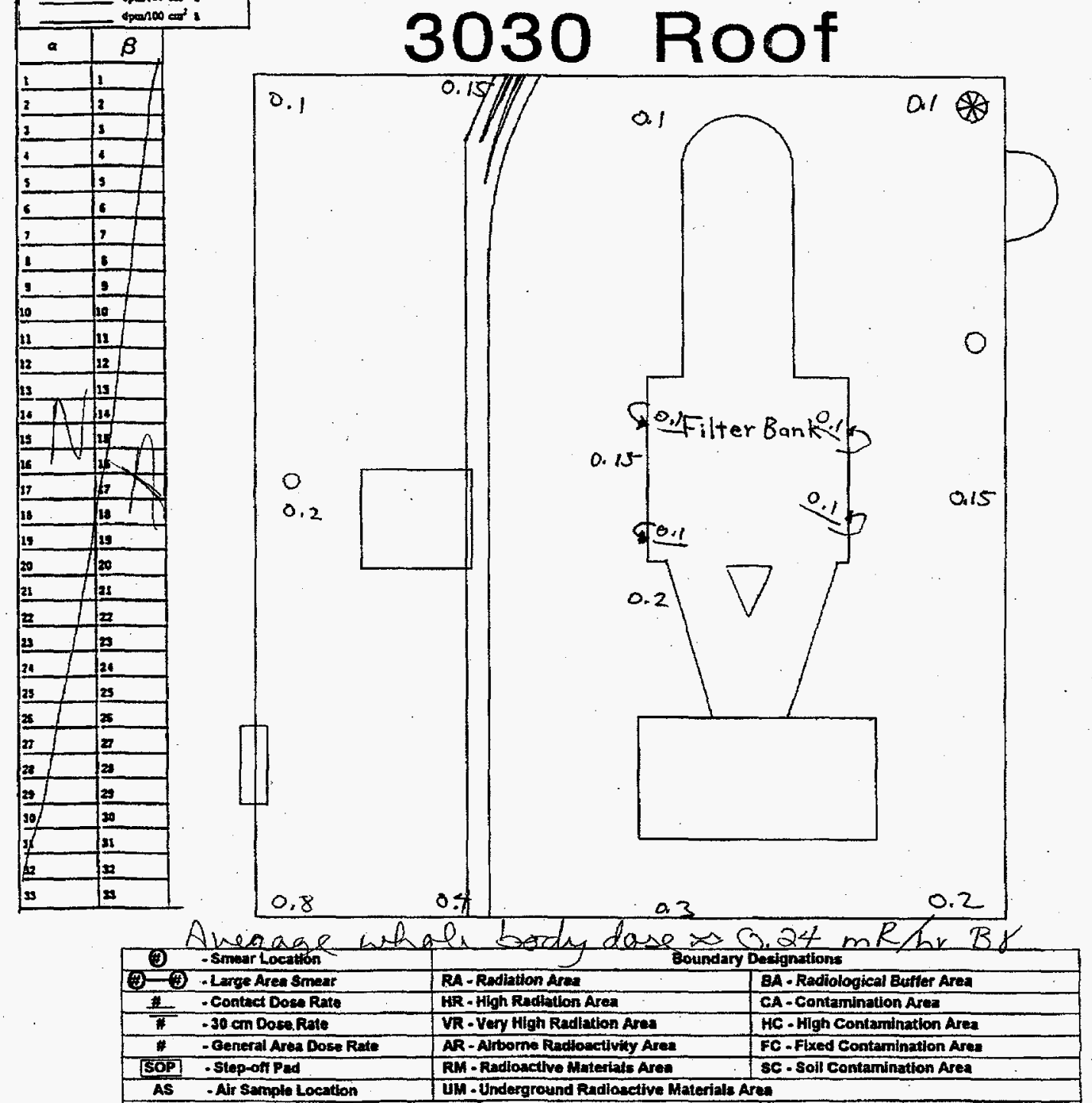
Avinage what

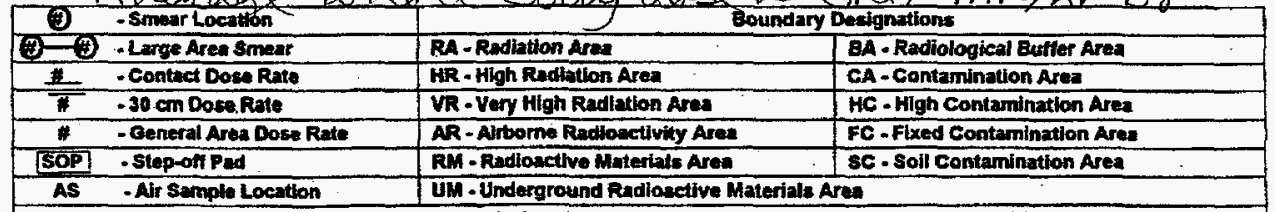
Default units are in mRhr and are for open window betalgamme readings. Letter suffixes with the number indicate speciflc radiations: B - Beta (mRad/hr), G - Gamma (mR/hr), N - Neutron (mRem/hr). Boundary designations are looking from the designations into the zoned area. 

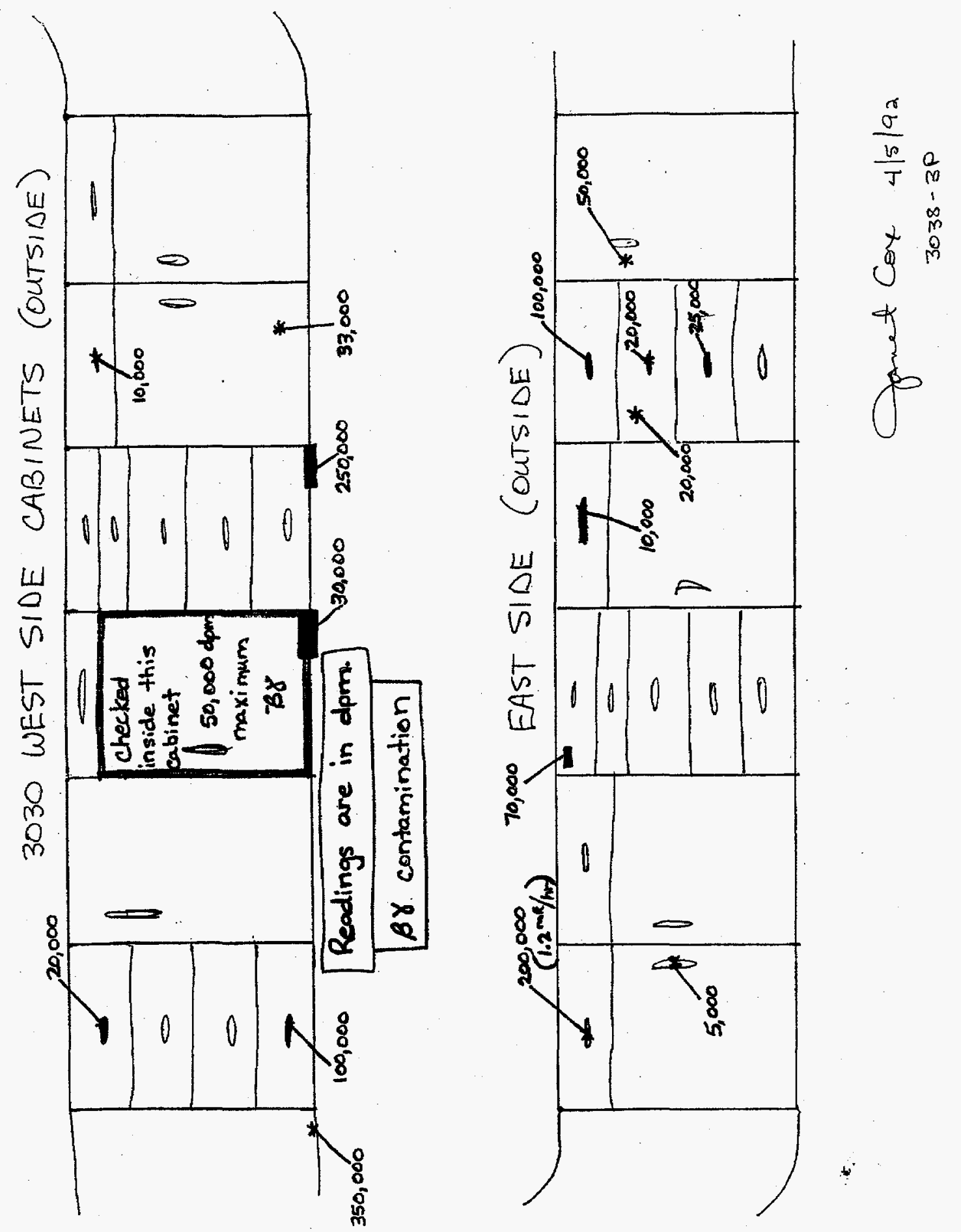


\section{ORNL Radiological Survey Data}

survey Mumber: $3038.95 \cdot 1285 \quad 3038$ Field Office Date: 21/4/95 Thme: 0800

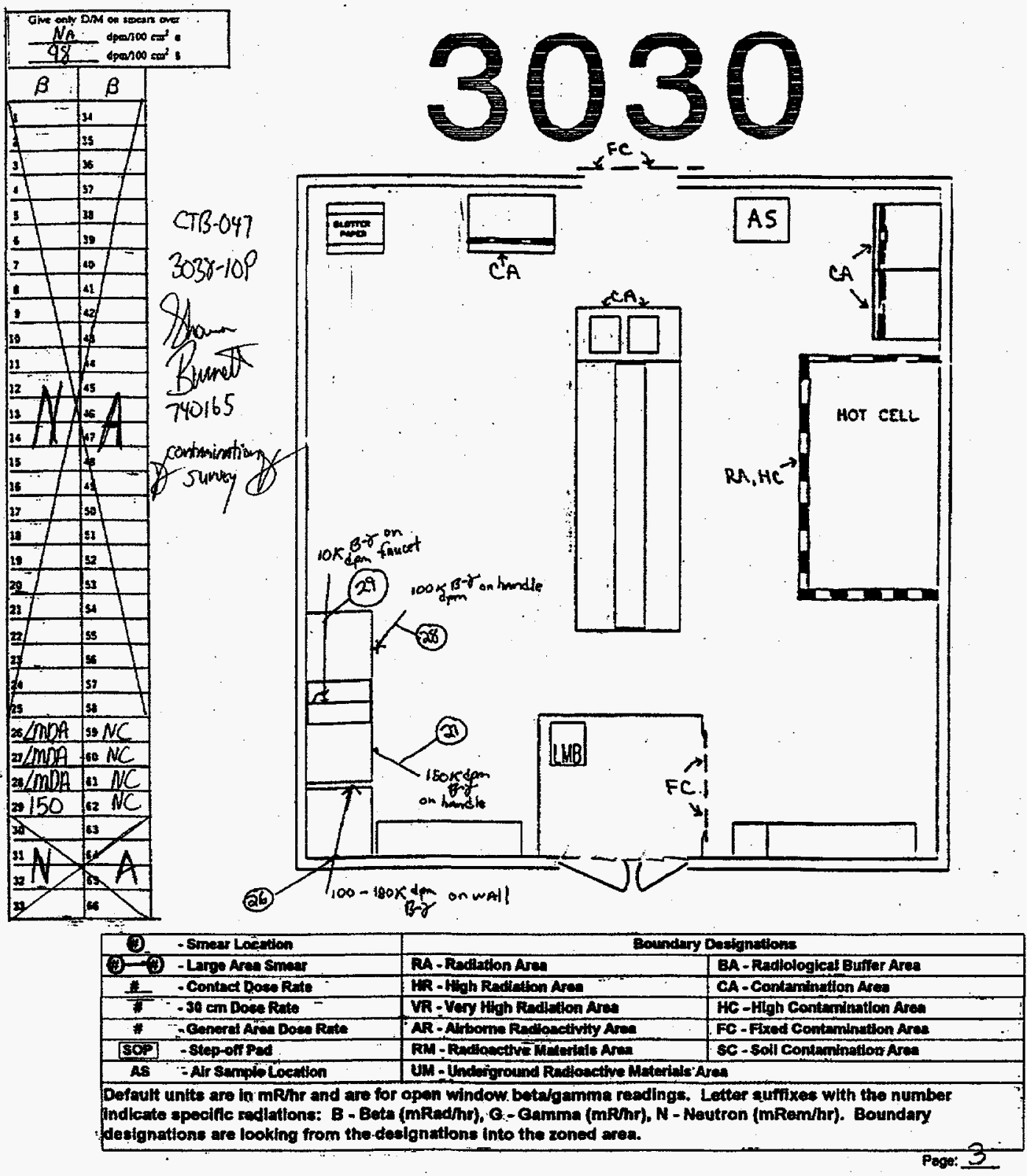




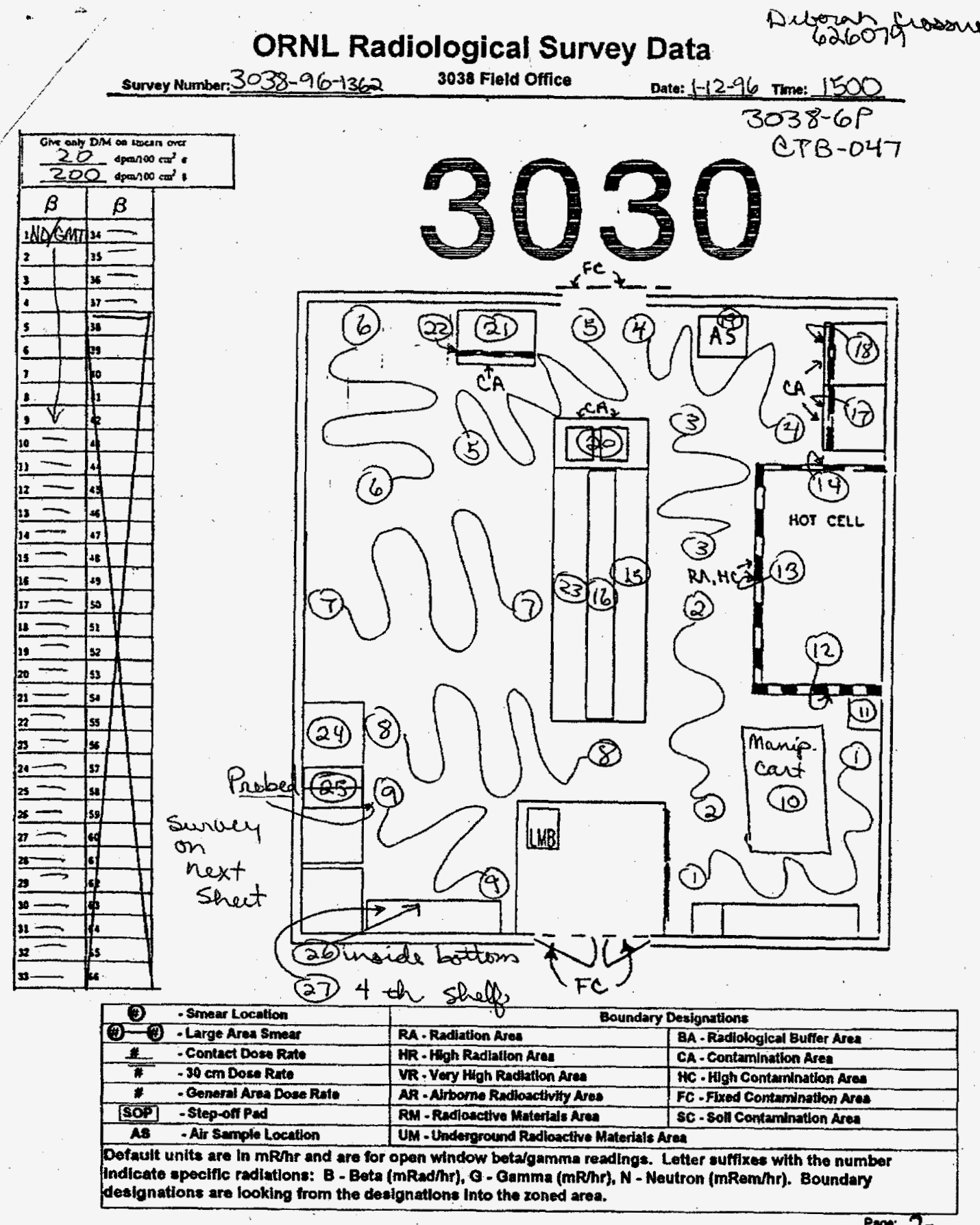

Pape: 2 


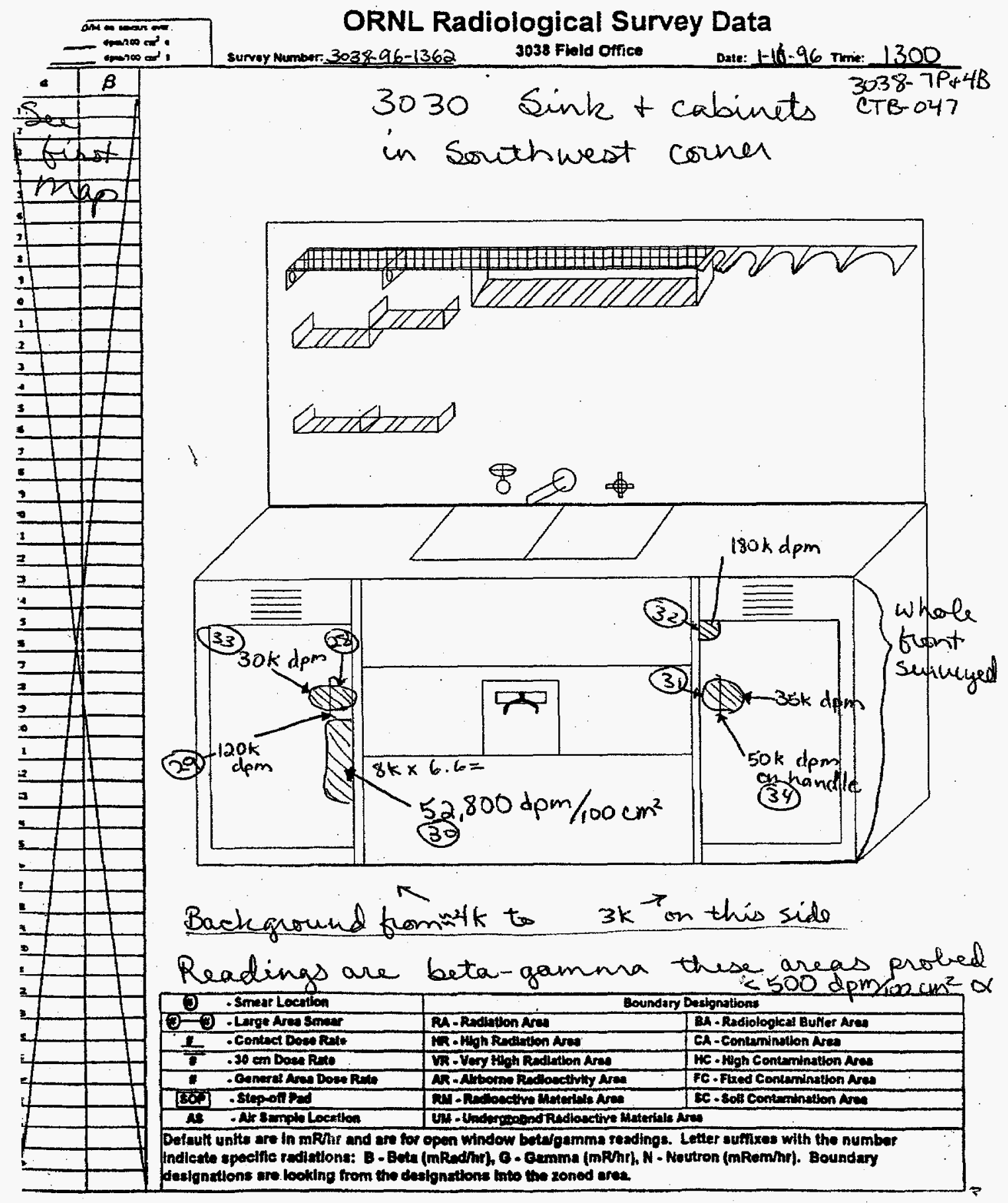




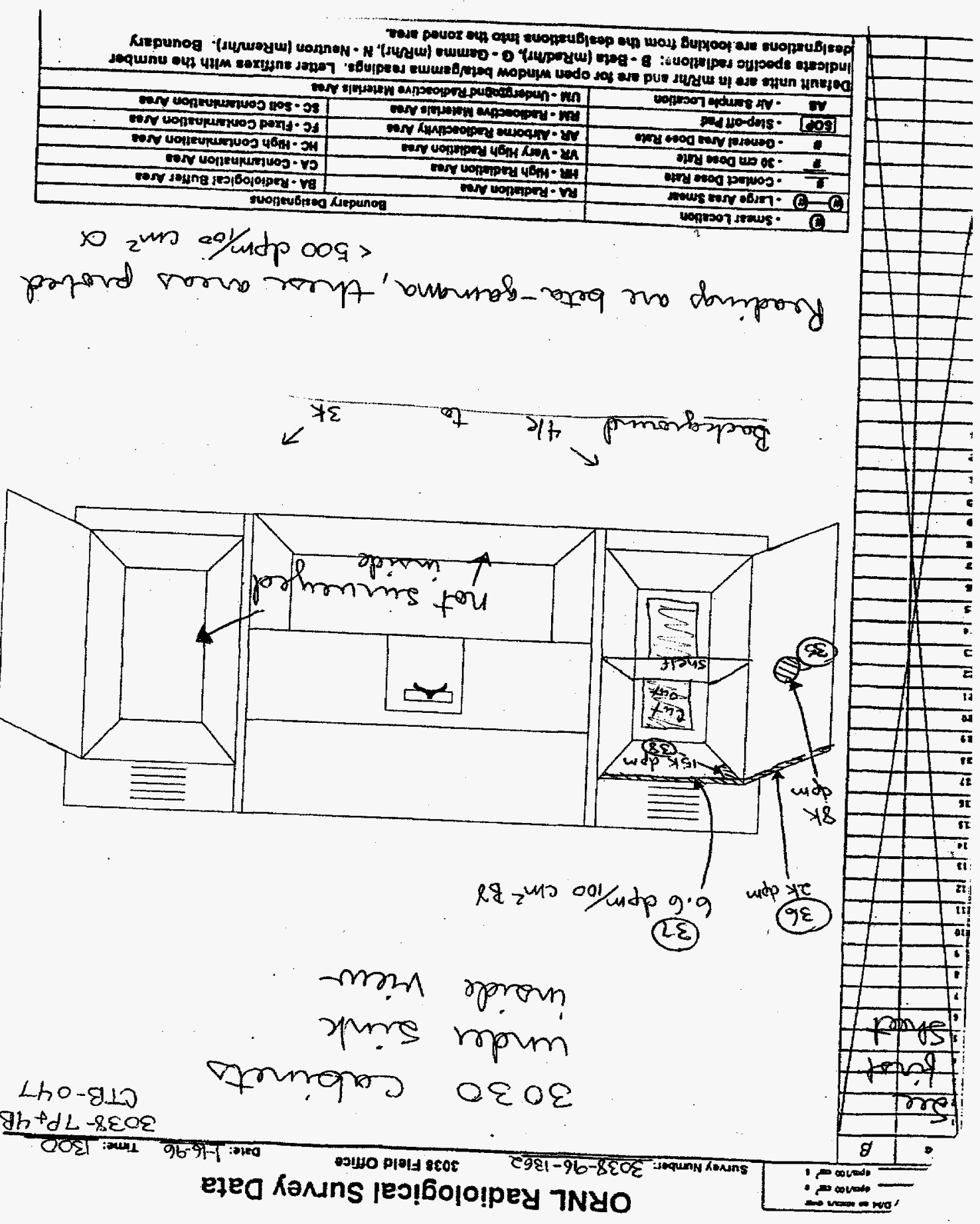




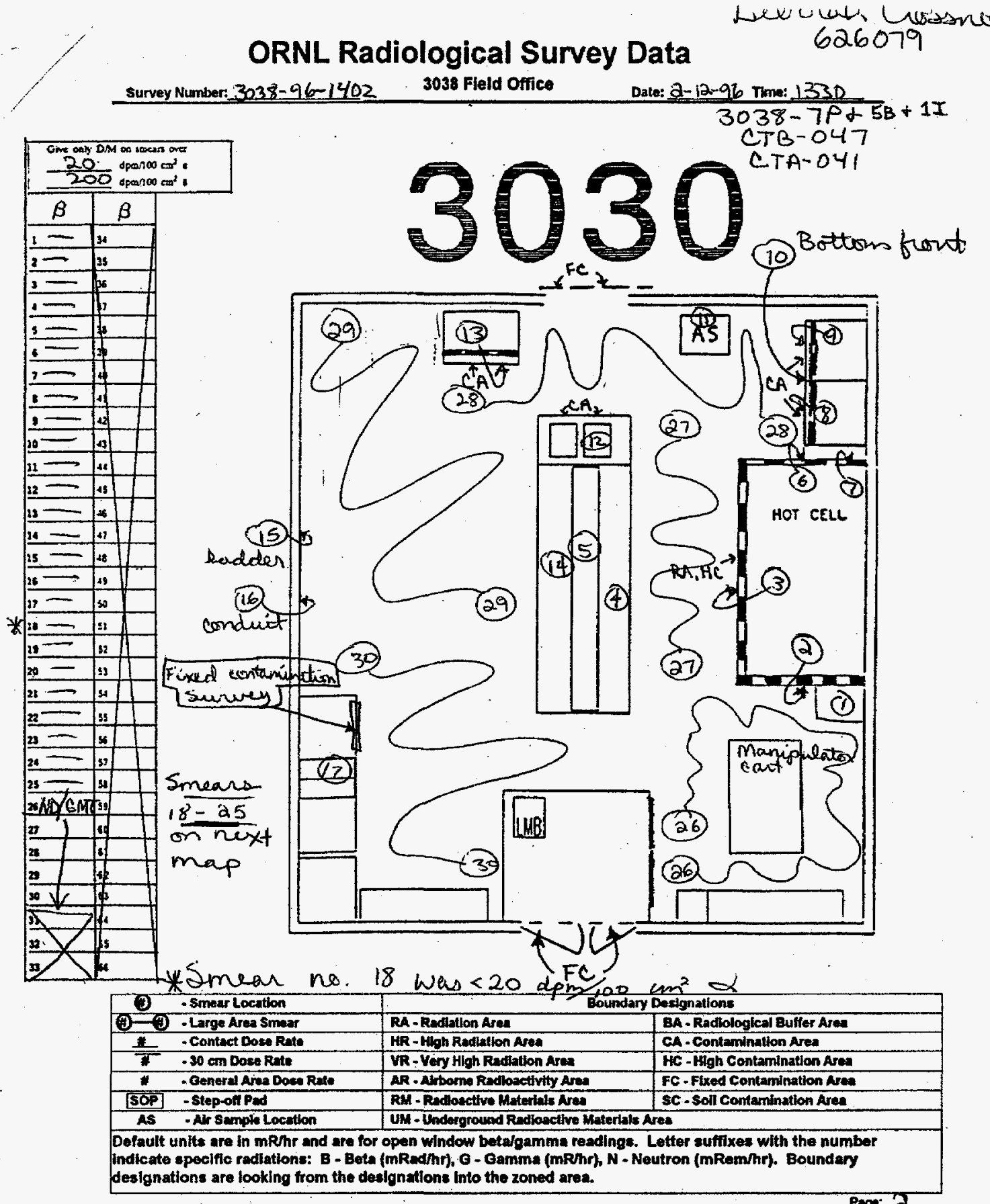

Page: 2 


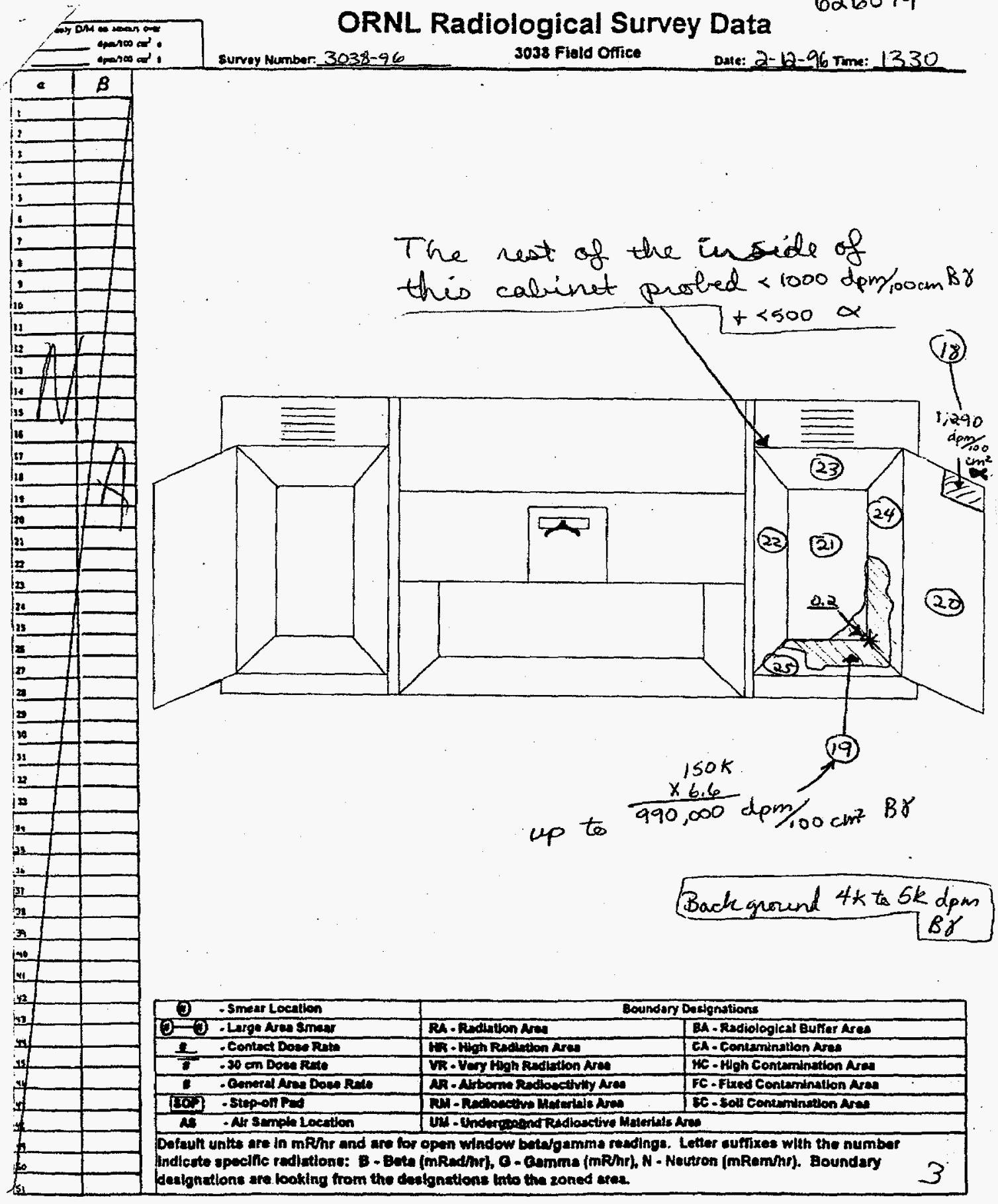




\section{ORNL Radiological Survey Data}

survey Number: $3038.96-1584 \quad 3038$ Field Ofice Date: 5-15-96 Tum: $11: 00$
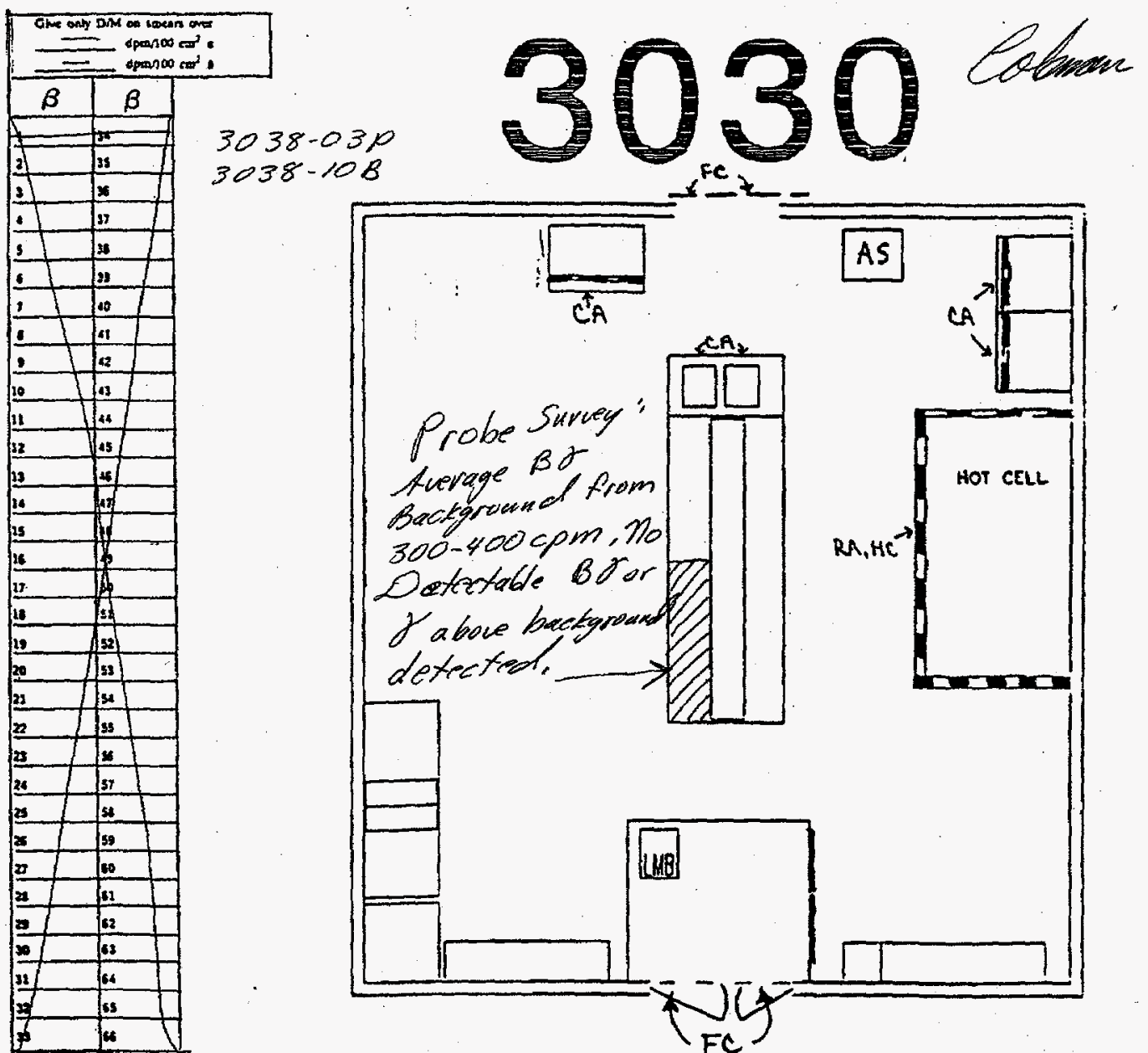

$3038-03 p$ $3038-10 B$<smiles></smiles>

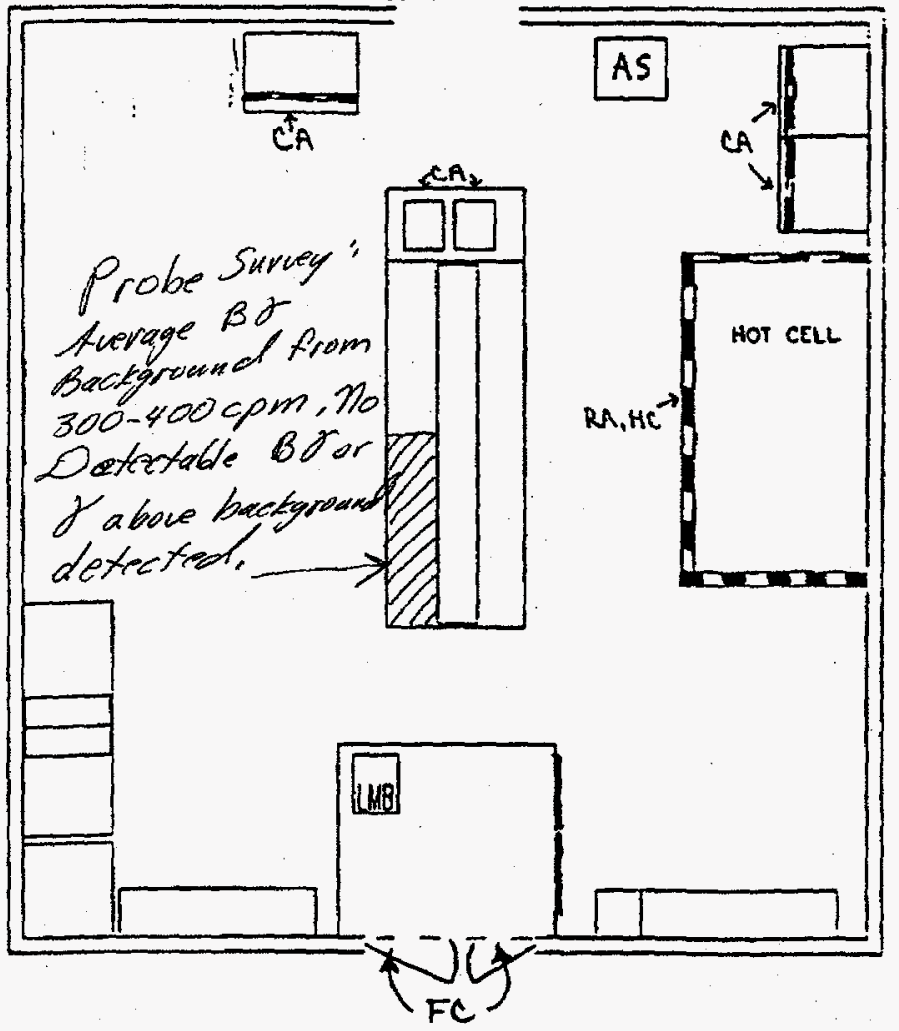

\begin{tabular}{|c|c|}
\hline 7 & - Smear Location \\
\hline$=0$ & - Large Ares Smear \\
\hline$\#$ & - Contact Dase Roto \\
\hline$\%$ & -30 cin Dose Rate \\
\hline 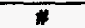 & - General Aros Dose Ruto \\
\hline$\sqrt{50}$ & - Step-off pod \\
\hline$A 8$ & - Alr Sempla Locention \\
\hline
\end{tabular}

RA. - Faviation Ares

Boundary Decignallone \begin{tabular}{l|l} 
BA-Radiological Buffer Area \\
\hline HR-
\end{tabular} HR - Hoh Radiation Area $\quad$ CA-Contarnination Area

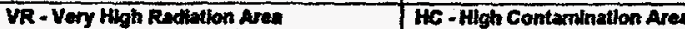

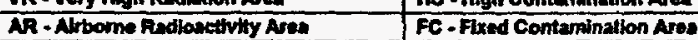
RM - Radionctive Matertale Aver UM - Undereround Radlosetive Matering Ares

Default units are In mRhr and are tor open window botalgamma readings. Letrer sufixes with the number indicate specific radlations: B - Beta (mRad/hr), $\mathrm{c}$ - Gemma (mR/hr), N-Neutron (mRem/hr). Boundary designations are tooking from the designstions into the zoned area. 


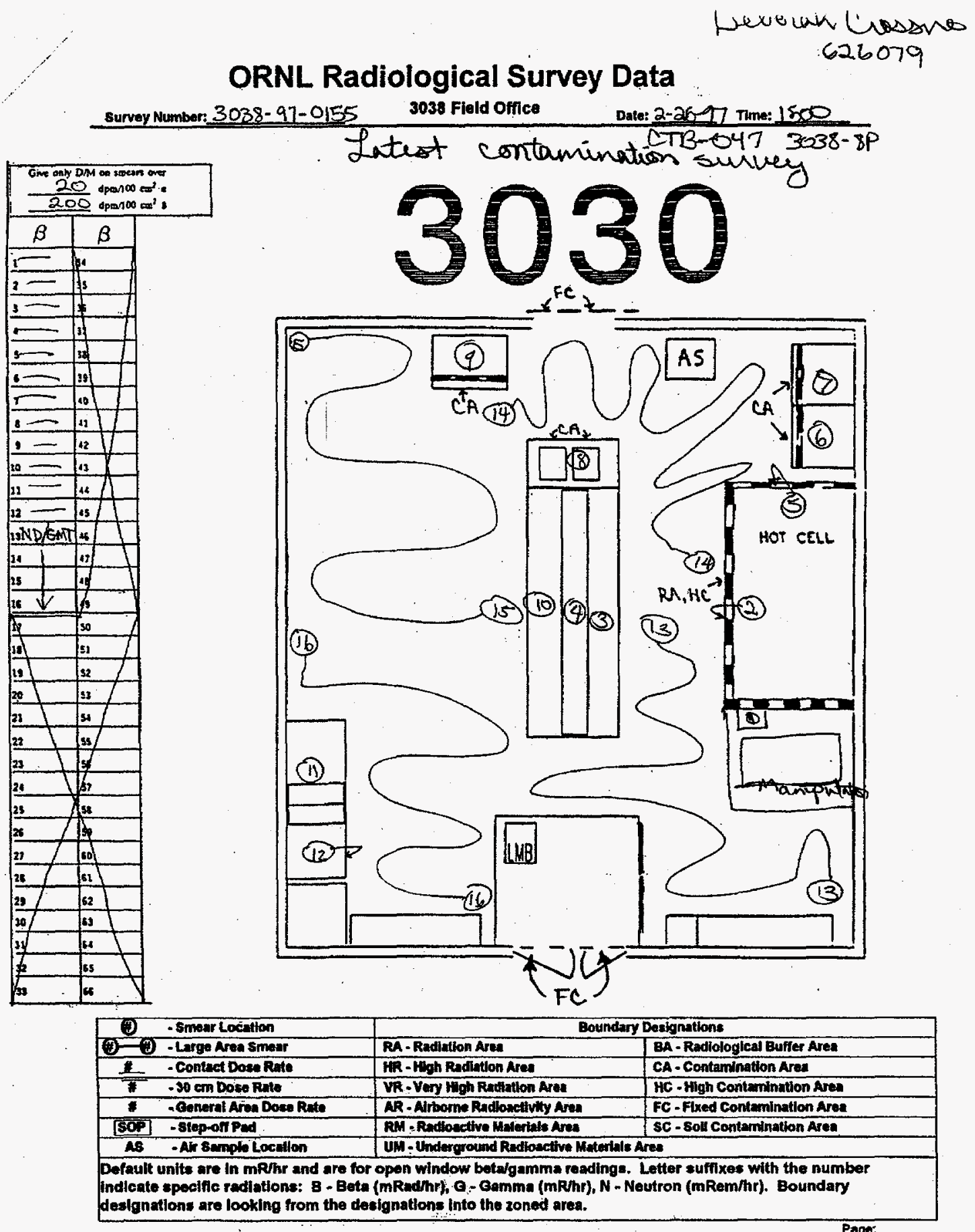




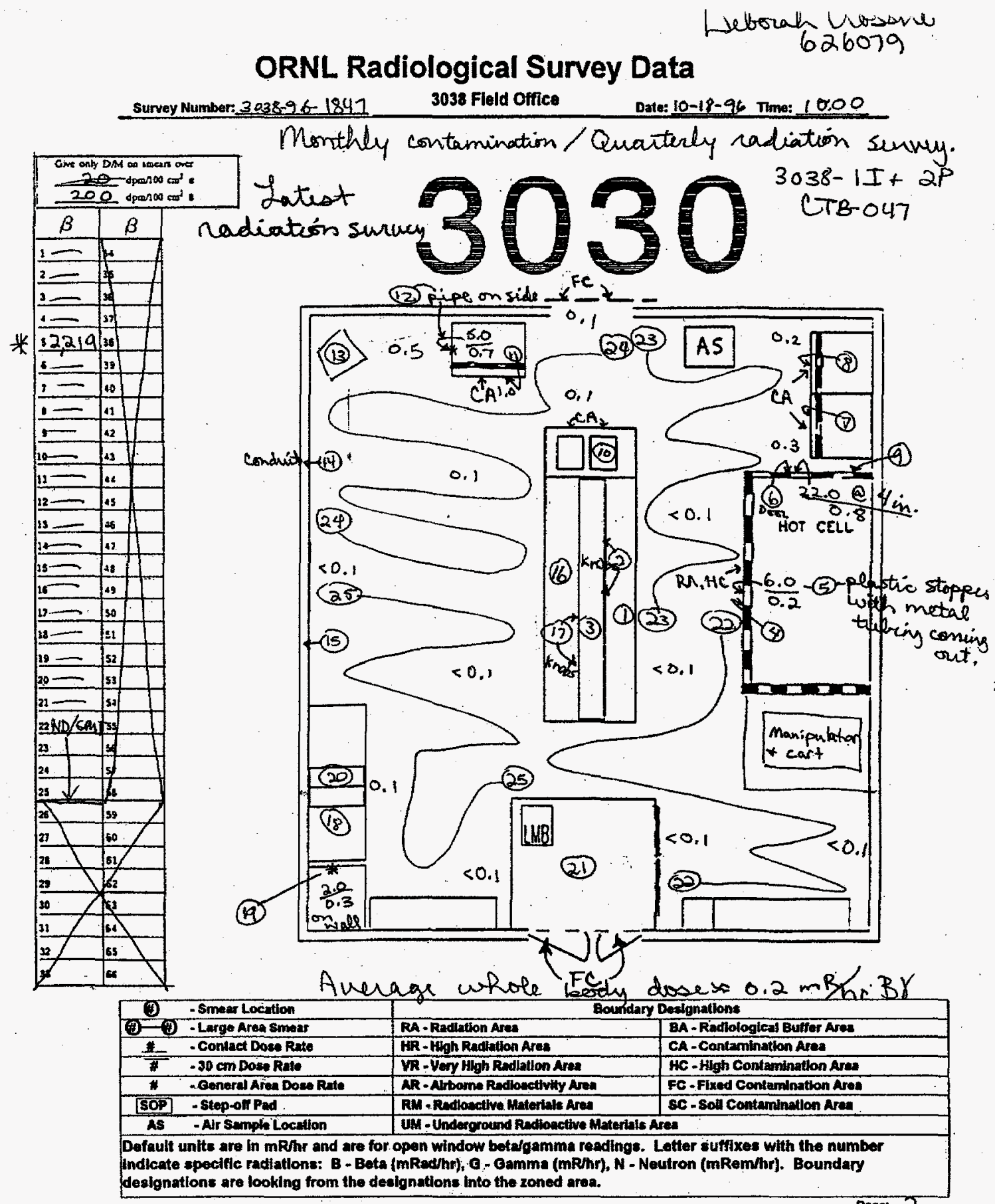
* Smear no. 5 was <200 dpm/100 $\mathrm{cm}^{2} B \gamma$ ofta deconning. 

ATTACHMENT 8

S\&M TURNOVER

PACKAGE CHECKLIST 

S\&M Turnover Package Checklist

\begin{tabular}{clc}
\hline Item Number & \multicolumn{1}{c}{ Document } & Applicable ? \\
\hline $\mathbf{1}$ & $\begin{array}{l}\text { Postdeactivation Surveillance and Maintenance Plan } \\
\mathbf{2}\end{array}$ & $\begin{array}{l}\text { Postdeactivation Surveillance and Maintenance Updated } \\
\text { Effluent Monitoring Plan }\end{array}$ \\
$\mathbf{3}$ & $\begin{array}{l}\text { Postdeactivation Surveillance and Maintenance Updated } \\
\text { Safety Equipment List }\end{array}$ & No \\
$\mathbf{4}$ & $\begin{array}{l}\text { Postdeactivation Surveillance and Maintenance Procedures } \\
\mathbf{5}\end{array}$ & $\begin{array}{l}\text { Postdeactivation Surveillance and Maintenance } \\
\text { Recommendations }\end{array}$ \\
$\mathbf{6}$ & Mothballed Systems Lay-up and Restart Documentation & Yo \\
\hline
\end{tabular}





\section{DISTRIBUTION}

1. L. V. Asplund

2. W. D. Brickeen

3. R. A. Brown

4. T. W. Burwinkle

5. K. Constant

6-15. R. E. Eversole

17. K. W. Haff

18. S. A. Herron

19. L. L. Kaiser

20. T. M. Koepp

21. P. T. Owen

22. L. D. Owens

23. B. D. Patton

24. L. B. Raulston

25. Central Research Library

26. File-EMEF DMC-RC 
